\title{
Mapping the missing branch on the neogastropod tree of life: molecular phylogeny of marginelliform gastropods
}

\author{
Fedosov Alexander E. 1, 2, ${ }^{*}$, Gutierrez Manuel Caballer ${ }^{2,3}$, Buge Barbara ${ }^{2}$, Sorokin Pavel, V ${ }^{1}$, \\ Puillandre Nicolas ${ }^{4}$, Bouchet Philippe ${ }^{2}$
}

\begin{abstract}
${ }^{1}$ Russian Acad Sci, AN Severtsov Inst Ecol \& Evolut, Leninskiy Prospect 33, Moscow 119071, Russia.
2 Sorbonne Univ, Museum Natl Hist Nat, Inst Systemat Evolut Biodiversiti ISYEB, UMR

7205,CNRS,UPMC,EPHE, 55 Rue Buffon,CP26, F-75005 Paris, France.

${ }^{3}$ Amer Univ Paris, Dept Comp Sci Math \& Environm Sci, 102 Rue St Dominique, F-75007 Paris, France.

${ }^{4}$ Sorbonne Univ, Inst Systemat Evolut Biodivetsite ISYEB, Museum Natl Hist Nat, CNRS,EPHE, 57 Rue Cuvier,CP 26, F-75005 Paris, France.
\end{abstract}

* Corresponding author : Alexander E. Fedosov, email address : fedosovalexander@gmail.com

\begin{abstract}
:
Marginelliform gastropods are a heterogeneous and diverse group of molluscs encompassing over 1,600 living species, among which are the smallest known neogastropods. The relationships of marginelliform gastropods within the order Neogastropoda are controversial, and the monophyly of the two marginelliform families the Marginellidae(J. Fleming, 1828 and the Cystiscidae Stimpson, 1865, remains unconfirmed. DNA sequence data have never been used to assess the relationships of the marginelliform gastropods, making this group the only major branch missing in our current understanding of the neogastropod tree of life. Here we report results of the first multilocus phylogenetic analysis of marginelliform gastropods, which is based on a dataset comprising 63 species (20 genera) of Marginellidae and Cystiscidae, and a wide range of neogastropod lineages. The Marginellidae and Cystiscidae form a moderately supported Glade that is sister to the family Volutidae. Marginellona gigas appears to be sister to all other marginelliforms. The subfamily Marginellinae was recovered as a wellsupported Glade, and good resolution of this part of the tree makes it possible to propose amendments to the family-level classification of the group. The relationship between Granulina and other marginelliforms could not be resolved and requires further study. Due to poor resolution of basal relationships within the Marginellidae Cystiscidae Glade, the monophyly of the Cystiscidae was neither confirmed nor convincingly rejected. The shell morphology of most marginellid and cystiscid genera is taxonomically not very informative but, nevertheless, of the traditionally recognized genera only Gibberula and Dentimargo were shown to be polyphyletic. Although a comprehensive systematic revision of the group requires more extensive taxonomic sampling (e.g. with better representation of the type species of nominal genus -group names), our results support the superfamily Volutoidea, comprising four families (Volutidae, Cystiscidae, Marginellidae and Marginellonidae), with the placement of the Granulinidae uncertain for the time being.
\end{abstract}


The so-called maginelliform gastropods of the families Marginellidae and Cystiscidae harbour an impressive diversity of over 1,600 described living species (MolluscaBase, 2019; for taxonomic authorities, see revised classification below). This includes the smallest known neogastropod, Ticofurcilla mariolysae Ortea, 2016 (Fig. 1A), the adults of which attain a length of just $1.35 \mathrm{~mm}$ (Ortea, 2016). The shell morphology of marginelliform gastropods is taxonomically uninformative. These molluscs generally possess ovate or elongate shells, which are either involute or low-spired and have a distinctly thickened margin of the outer lip (Coovert \& Coovert, 1995). The shell surface usually lacks sculpture and is glossy and translucent -with some remarkable exceptions, e.g. the shell of Extra extra Jousseaume, 1894 is rough and strongly ribbed. The origin of marginelliforms dates back to at least the Eocene (Wenz, 1938) or late Cretaceous (Ponder, 1973: the genus Myobarbum Sohl, 1963). Recent marginellids and cystiscids occur predominantly in tropics, being about equally diverse in the Indo-Pacific and Atlantic (West Africa and Caribbean); the most iconic species, such as those in the genera Marginella and Persicula, occur mainly outside the Indo-Pacific.

Detailed anatomical studies of the marginelliforms (Ponder, 1970; Fretter, 1976; Coovert \& Coovert, 1995) have revealed an extraordinary diversity of alimentary canal arrangements and this has been reflected in the revised classification proposed by Coovert \& Coovert (1995). This classification, which was based on a broad taxonomic sampling and a substantial number of characters, presented a generally plausible scheme for relationships within major marginelliform lineages. Relationships among these lineages, however, remain uncertain and differing interpretations of character evolution have led to conflicting phylogenetic hypotheses (Harasewych \& Kantor, 1991; Coovert \& Coovert, 1995; de Souza, 2007; de Souza \& Simone, 2019). The relationships between the Marginellidae, Cystiscidae and other neogastropod taxa also remain poorly understood. Some marginelliforms have a uniseriate radula and a set of anatomical features that are shared with the Volutidae. This suggests common ancestry with the Volutidae and thus that the marginelliforms belong to a lineage that originates from a split deep in the neogastropod tree (Ponder, 1973; Harasewych \& Kantor, 1991). However, evidence for this hypothesis is poor; it is supported by only few characters, which are either plesiomorphic or likely to be the result of convergent evolution (Ponder, 1973; Kantor, 2002). 
The extensive molecular phylogenetic studies of the last decade have profoundly changed our understanding of the systematics of Neogastropoda. Marginelliforms, however, have not been included in these studies. DNA sequence-based analyses of species limits and phylogenetic relationships are lacking for marginelliform gastropods and, remarkably, not a single DNA sequence of a marginellid or cystiscid has to date been deposited in GenBank. Therefore, the monophyly of the main lineages of marginelliform gastropods remains unconfirmed, as well as their affinities to other neogastopod taxa.

Until the recognition of the Cystiscidae Stimpson, 1865, based on the peculiar morphology of head and radula of Cystiscus, marginelliform gastropods were classified in the single family Marginellidae. Coan (1965) ranked Cystiscinae (with Cystiscus, Cypraeolina CerulliIrelli, 1911 and Kogomea Habe, 1951 as constituent genera) as a subfamily of Marginellidae, and established a third subfamily Marginelloninae for the genera Marginellona and Afrivoluta. The classification proposed by Coovert \& Coovert (1995) considered the Marginellidae and Cystiscidae to be separate families. In this classification the Marginellidae consisted of the subfamilies Marginellinae (with tribes Marginellini, Austroginellini and Prunini), Marginelloninae and a new subfamily, Granulininae. The Cystiscidae also comprised three subfamilies, the Cystiscinae, Persiculinae and Plesiocystiscinae, and included the genera Gibberula and Persicula, which had formerly been placed in the Marginellidae. Furthermore, on the basis of substantial differences in radular apparatus and the morphology of the head, Coovert \& Coovert (1995) argued that the Cystiscidae and Marginellidae were not closely related. The current classification of Bouchet et al. (2017) essentially follows that of Coovert \& Coovert (1995).

The genus-level taxonomy of the Marginellidae and Cystiscidae is also problematic. Early attempts to establish genus-level classifications of marginelliform gastropods (reviewed by Coan, 1965) suffered notably from inconsistent use of names; phases when genus-level taxa were proliferating have alternated with periods of extensive lumping. There have been three major recent bursts in the description of supraspecific taxa. The first was associated with the work of Laseron (1957), who reassigned Australian species of marginellids to some 30 genera. The work of G.A. Coovert and H.K. Coovert followed on from this and culminated in a comprehensive revision of marginelliform gastropods (Coovert \& Coovert, 1995). The more recent studies by J. Espinosa, J. Ortea and co-workers have been largely focused on Caribbean taxa (Ortea, 2014; 2016; Ortea, et al. 2019). 
109 Notwithstanding, the concept of widespread and speciose marginelliform genera, such as

110 Gibberula, Cystiscus, Volvarina Hinds, 1844 and Marginella, each comprising species from the

111 Indo-West Pacific, eastern Atlantic, and Caribbean, remains mainly based on shell features, and

112 calls for a critical reassessment.

113 Using molecular phylogenetic analyses, based on a total of five mitochondrial and nuclear loci,

114 the present study seeks to clarify the relationships between the marginelliforms and other

115 neogastropods, to assess the validity of currently recognized marginelliform families and

116 subfamilies and to provide a revised family-level classification for this group. 
The present study is based largely on material collected during expeditions conducted by Muséum National d'Histoire Naturelle (MNHN) to New Caledonia (KANACONO, EXBODI), Western Australia, Tasmania and Papua New Guinea (PAPUA NIUGINI, KAVIENG 2014, MADEEP), the South China Sea (DongSha), Mozambique (INHACA 2011, MAINBAZA), South Madagascar (ATIMO VATAE), Congo (Mission ZANAGA), Senegal (DAKAR), French Guiana (ILES DU SALUT, ACUPA), Guadeloupe (KARUBENTHOS 2) and Martinique (MADIBENTHOS). Additional specimens were contributed by AF (the Philippines, collected in cooperation with the University of the Philippines, 2016) and FB (Oman), or were received on loan from the University of Vienna (Table 1). The accessed specimens represent three tropical biogeographical regions (as defined by Briggs \& Bowen, 2012): the Indo-West Pacific, West Indian Ocean and Atlantic (including West Africa and Caribbean), as well as the warm temperate waters of the Mediterranean, Tasmania and southwestern Australia.

Marginelliform gastropods are often very small and possess a narrow, slit-shaped aperture, so that if living animals are preserved by immersion in ethanol, proper tissue fixation is hampered and the extraction of DNA of appropriate quality is often problematic. In this study, therefore, we used only recently collected specimens (starting in 2013), with most having been tissue-clipped in the field. Most of these specimens were processed using a microwave oven (Galindo et al., 2014), followed by subsequent preservation of tissue samples in $96 \%$ ethanol. Whenever possible, live animals were imaged prior to tissue sampling, in order to record details of the morphology and colouration of the body in its living state (Fig. 1). Vouchers of shells have been deposited in MNHN, Natural History Museum Vienna or in the Laboratory of Ecology and Morphology of Marine Invertebrates at the A.N. Severtsov Institute of Ecology and Evolution of Russian Academy of Sciences (IEE), Moscow.

Specimens were initially sorted into morphospecies based on shell morphology. Then the barcode fragment of the cytochrome $c$ oxidase subunit I (COI) gene was sequenced for up to four specimens of each morphospecies (results not shown).Phylogenetic relationships between marginelliform taxa were investigated by reconstructing a phylogeny based on five genes: three mitochondrial genes (COI, 16S rRNA and 12S rRNA) and two nuclear genes (histone $3(\mathrm{H} 3)$ and $28 \mathrm{~S}$ rRNA). Marginelliform species for this phylogeny were selected by assessing the status of 
the morphospecies using molecular systematic data for the COI gene. We analysed pairwise Kimura 2-parameter distances for COI (following Puillandre et al., 2012, the threshold between intraspecific and interspecific variation was taken as 3\%) and assessed the monophyly of individual morphospecies in a phylogeny based on COI data. The generally low number of specimens sequenced for each morphospecies precluded the use of automatic species delimitation tools, such as that of Puillandre et al. (2012). Morphospecies selected for the multilocus phylogeny were each represented by a single specimen.

Applying species names to the morphospecies identified by us was often problematic because of the generally uninformative shell morphology of marginelliforms and the scarcity of data on the colouration of living animals. Uncertain species-level identifications were indicated by the use of 'cf.' (e.g. Eratoidea cf. hematita) and 'aff.' (e.g. Gibberula aff. moscatellii). In total, 27 of the 63 marginelliform species included in our phylogenetic analysis were identified only to genus level.

A total of 86 specimens from 20 nominal genera ( $47 \%$ of the 43 extant and currently recognized genera) were included in the multilocus dataset; these represent the three currently recognized subfamilies of Marginellidae, the three proposed tribes of Marginellinae, as well as the three subfamilies of Cystiscidae. Whenever possible, nominal genera were represented by multiple species that were collected from widely separate geographical localities; the aim was to confirm the monophyly of genera that are currently considered to have circumtropical distribution and to assess whether phylogenetic structuring in such genera reflects the distance between sampling locations. Only about $43 \%$ of the marginelliform species in our dataset could be confidently identified and this included just three type species of nominal genera (Marginellona gigas (Martens, 1904), Gibberula oryza (Lamarck, 1822) and Prunum prunum (Gmelin, 1791)). Thus, the results of our phylogenetic analyses are of limited value for taxonomic revisions below the subfamily level.

The monophyly of marginelliform gastropods has never been investigated using DNA sequence data and in an effort to do so we included 58 non-marginelliform species, belonging to 40 caenogastropod families. These non-marginelliforms represented a wide range of neogastropod lineages; sequence data were either from published studies (Zou et al., 2011; Claremont et al., 2012; Fedosov et al., 2015, 2017, 2018; Galindo et al., 2016; Kantor et al., 2017) and retrieved from GenBank, or were generated specifically for this study. 
181

DNA extraction and PCR were carried out as described by Fedosov et al. $(2017,2018)$. The amplification of the $28 \mathrm{~S}$ rRNA fragment was carried out as detailed by Kantor et al. (2018). In total, six molecular datasets were analysed, five single-gene datasets and one concatenated dataset containing all five mitochondrial and nuclear genes. The single-gene phylogenetic reconstructions were congruent (see below), so a five-gene concatenated dataset (3018 bp; referred to hereafter as the MaCys-5G dataset) was assembled. Sequences were aligned using Muscle v. 3.8.425 (Edgar, 2004) and the alignments edited manually where necessary. COI and H3 alignments were translated using BioEdit v. 7.2.0.0 (Hall, 1999) to ensure that the corresponding amino-acid sequences were not interrupted by stop codons.

The best-fit substitution models were identified for each gene separately using Partition Finder2 (Lanfear et al., 2016). The single-gene datasets of 12 S rRNA, 16S rRNA, H3 and $28 S$ rRNA were analysed as a single partition each, whereas the 1st, 2 nd and 3rd codon positions of $\mathrm{COI}$ were treated as three distinct partitions. The MaCys-5G dataset thus comprised seven unlinked partitions.

Best-scoring maximum likelihood (ML) trees were estimated using RaxML v. 8.2.12 (Stamatakis, 2006) and IQtree v. 1.6.10 (Nguyen et al., 2014). RaxML analyses were based on 1000 iterations of the thorough bootstrapping algorithm (Felsenstein, 1985). IQtree analyses were run with the best nucleotide substitution model selected by Model Finder Plus (Kalyaanamoorthy et al., 2017) and using 1000 iterations of the ultra-fast bootstrap strategy (Nguyen et al., 2014). Bayesian analyses were performed in two parallel runs in MrBayes v. 3.2.6 (Huelsenbeck et al., 2001). For the COI, 16S rRNA, 12S rRNA, 28S rRNA and H3 single-gene analyses, each Bayesian run consisted of six Markov chains and 10,000,000 generations, with default number of chain swaps and a sampling frequency of one tree every 1,000 generations. For the MaCys-5G dataset, Bayesian analyses were performed with the following parameter settings: number of chains $=8$, number of generations $=30,000,000$, number of chain swaps $=5$ and sampling frequency $=1$ tree every 1,500 generations. A chain temperature of 0.02 was used in all analyses. Convergence was assessed using Tracer v. 1.4.1 (Rambaut et al., 2014); the runs were considered to have converged if all ESS values exceeded 200. Consensus trees were calculated after discarding the first $25 \%$ of trees as burn-in. RaxML and Bayesian analyses were 
performed on the Cipres Science Gateway (http://www.phylo.org/portal2 - Miller et al., 2010). The IQ tree analysis was run locally on a 32-CPU working station. All trees were rooted on the outgroup taxon Xenophora sp. (Xenophoridae). for RaxML, BS2 for IQtree) values were $\geq 70 \%$ and posterior probability (PP) values were $\geq 0.95$, respectively.

\section{Morphological studies}

217 In many cases all the tissue retrieved from a specimen was used for DNA extraction In other cases, use of a microwave for tissue extraction prevented subsequent study of fine morphology. Fortunately, a comprehensive analysis of marginelliform anatomy was provided by Coovert \& Coovert (1995), so their data were re-examined in the light of the molecular phylogeny. One aspect of internal anatomy that we were able to investigate in detail and compare with descriptions by Coovert \& Coovert (1995) was the radula. We studied the radula of all the marginelliform taxa included in our phylogeny. For each morphospecies included in the phylogeny, we tried as far as possible to examine the radula of the sequenced specimen; when this was not possible a specimen collected from the same exact locality as the sequenced specimen was used. For larger specimens the radulae were extracted by dissecting out the foregut complex and dissolving the tissue in a $5 \%$ solution of commercial bleach; in the case of smaller specimens all tissue was simply dissolved in $5 \%$ bleach solution. Following the removal of associated soft tissue, the radulae were rinsed in several changes of distilled water and mounted on 12-mm coverslips for investigation by scanning electron microscopy (SEM). The airdried radulae were then gold-coated. Examination and imaging by SEM was performed using a Hitachi Jeol SEM and a TeScan TS5130MM SEM, at MNHN and IEE, respectively. 
While the single gene trees were generally congruent with each other, neither the placement of marginelliform lineages within the Neogastropoda, nor relationships between marginelliform taxa were strongly supported. In the analyses of the multilocus dataset, the topology and levels of branch support were strikingly different between analyses including and excluding the two species of Granulina. Although Granulina was always shown to fall within the main Marginellidae + main Cystidae clade (see Supplementary Material Fig. S1), its position was unstable and its inclusion tended to reduce support values across the tree. Therefore, the final analyses (i.e. those discussed below) were carried out without Granulina.

Our ML (IQtree and RaxML) and Bayesian trees were largely congruent for relationships among neogastropod families and superfamiles, but deeper relationships were generally poorly resolved and the branching order varied depending on the method of phylogenetic reconstruction. Our analyses consistently recovered two major clades (Fig. 2): a clade comprising the marginelliforms and the Volutidae, which was strongly supported in two of the three main analyses $(\mathrm{PP}=0.97, \mathrm{BS} 2=88 \%)$, and a consistently strongly supported clade $(\mathrm{PP}=1$, $\mathrm{BS} 1=76 \%, \mathrm{BS} 2=97 \%$ ) consisting of the remaining neogastropod taxa, the Ficoidea and the Tonnoidea. The monophyly of the marginelliforms, although recovered in all analyses, was strongly supported only in the IQ tree (BS2 = 95).

The first split within the marginelliforms separates Marginellona gigas from a consistently well-supported clade containing all the remaining species (PP = 1, BS1 $=73 \%$, BS2 $=100 \%$; Fig. supported in the IQtree: BS2 = 100\%), (2) Canalispira (strongly supported in all three analyses: $\mathrm{PP}=1, \mathrm{BS} 1=100 \%, \mathrm{BS} 2=100 \%$ ), (3) Plesiocystiscus (strongly supported in the IQ tree: BS2 = 91\%) and (4) the 'Main Marginellidae' clade (always strongly supported: $P P=1, B S 1=100 \%$, BS2 $=100 \%)$. basis of shell characters, belong to five nominal genera in the subfamilies Cystiscinae and 
Persiculinae: Cystiscus, Crithe, Gibberula, Persicula and Pachybathron. Together, Cystiscus and Crithe always formed a maximally supported clade (MC1 subclade) that contains species from both the Indo West Pacific (IWP) and the Caribbean. The MC2 subclade (also maximally supported) comprises two Caribbean species with similar shells ornamented with a pattern of lines: Gibberula aff. moscatellii Boyer, 2004 and Persicula pulcherrima (Gaskoin, 1849). The well supported MC3 subclade (PP = 1, BS2 = 99\%) consists of six small unidentified species, mostly from the Indo-Pacific; despite substantial variability in shells morphology, these were tentatively attributed to Gibberula (4 species) and Persicula (one species, from Oman). The MC4 subclade is a strongly supported clade comprising two West African species of Gibberula and G. nebulosa Boyer, 2002, from deep water off New Caledonia (note the deep divergence between the West African taxa and G. nebulosa). Finally, the strongly supported MC5 subclade (PP =1, $\mathrm{BS} 1=99 \%, \mathrm{BS} 2=100 \%)$ comprises three Caribbean taxa: two species of Pachybathron and 'Gibberula' colombiana Boyer, 2003. The relationships among the five subclades of the Main Cystiscidae clade were unresolved. The monophyly of each of the genera Cystiscus and perceived, are not monophyletic.

\section{'Main Marginellidae' clade}

The Main Marginellidae clade includes 40 sequenced species, grouped into two strongly supported subclades, $\mathrm{MM} 1(\mathrm{PP}=1, \mathrm{BS} 1=99 \%, \mathrm{BS} 2=100 \%)$ and the $\mathrm{MM} 2+\mathrm{MM} 3+\mathrm{MM} 4$ subclade $(\mathrm{PP}=1, \mathrm{BS} 1=99 \%, \mathrm{BS} 2=100 \%)$. The MM1 subclade comprises 13 sequenced species (all from the west Pacific, and only 3 confidently identified) in the genera Serrata, Protoginella, Mesoginella, Hydroginella, and Dentimargo. Three of the four well supported groups that constitute MM1 consist of species that occur exclusively in deep water; on the basis of shell

The MM2 subclade is maximally supported and comprises ten species in two strongly supported clusters. The first cluster consists of two shallow-water species from Papua New Guinea, which have been tentatively assigned to Dentimargo. The second cluster is composed 
of eight deep-water species of Dentimargo, Marginella and Eratoidea from New Caledonia and the Caribbean. The MM3 subclade is maximally supported and consists of five described species of Marginella and Glabella Swainson, 1840, all exclusively from shallow water localities off the coast of South and West Africa. The MM2 and MM3 subclades were shown to be sister groups in two of the three main analyses $(B A, I Q)$. The strongly supported $M M 4$ subclade $(P P=1, B S 1=$ $81 \%$, BS2 $=100 \%$ ) consists of a pair of Closia species (from off Madagascar) and a large Volvarina-Prunum-Hyalina cluster uniting species from both shallow and deep-water localities in the Caribbean, South and West Africa and the IWP. Although deeper relationships within this group are generally well supported, no clear pattern can be observed with regard to geographic or bathymetric distribution.

Our results confirm the monophyly of the genera Hydroginella, Mesoginella, Protoginella and Closia, indicate that Dentimargo and Marginella are clearly polyphyletic, and demonstrate that Volvarina is paraphyletic in relation to Prunum and Hyalina.

\section{Morphology of the radula}

Radula morphology was studied in 26 sequenced species of marginelliform gastropods (including two species of Granulina); five other species were dissected, but no radula was found (Fig. 3). We also studied published SEM images of the radulae of Volvarina avena and V. lactea (Bandel, 1984; these are similar in shell morphology to the sequenced specimens MNHN-IM2013-60828 and MNHN-IM-2013-60956, respectively). The radulae examined correspond to the following radula types delineated by Coovert \& Coovert (1995): types 1-7, type 9 and the 'modified type 6' radula (Fig. 4). Only in type 1 radulae were transverse rows observed to have three teeth (Fig. 4A, B); the radulae of the remaining seven types are uniseriate and composed of rachidian teeth only. The distribution of radula types (Fig. 3) across our trees shows clear phylogenetic structuring. Cystiscid lineages are characterized by three types of radulae: type 1 (Plesiocystiscus Coovert \& Coovert, 1995; Fig. 4A, B), type 2 (Cystiscus; Fig. 4C, D) and a variable type 3 (all other lineages, including Canalispira Fig. 4E-L). All cystiscids have well-developed odontophoral hoods-wide, symmetrical chitinous lobes that are attached to the anterior part of the radula where it bends over the odontophore. According to Coovert \& Coovert (1995), these odontophoral hoods are supported by separate odontophore cartilages. The radula teeth of Plesiocystiscus sp. (Fig. 4B), 'Gibberula' nebulosa from New Caledonia (MNHN-IM-2013- 
68353, Fig. 4G), Canalispira sp. (Fig. 4I) and 'Persicula' sp. from Oman (Fig. 4K) showed pronounced wear.

Among marginellids included in our phylogeny, a 'modified type 6' radula is found in Serrata tuii (Cossignani, 2001) (MNHN-IM-2013-69537), an undescribed 'Dentimargo' species (MNHN-IM-2013-45628; Fig. 40) and in the two species of Closia. This radula type is characterized by wide, multicuspidate rachidians with a somewhat wavy anterior edge and subequal cusps. In contrast, 'true type 6' radulae have teeth that are distinctly rectangular, with a straight anterior edge and cusps of often unequal length; the surface of the tooth is marked by prominent pits, the function of which is to receive the cusps of the succeeding tooth (Fig. 4P). This type of radula, which is characteristic of the type species of Volvarina, V. mitrella (Ortea et al., 2014), was found in most members of the Volvarina-Prunum-Hyalina cluster of the MM4 subclade; the exceptions were Hyalina buskei Espinosa \& Ortea, 2013 (not shown on Fig. 4), Volvarina avena and V. lactea (Bandel, 1984). The very wide radula of Marginellona gigas (Fig. 4Q), in which each rachidian bears over 100 cusps, essentially does not differ from type 6 radulae, although we note that it was classified by Coovert \& Coovert (1995) in a separate category, type 7. Type 4 (Figs $4 \mathrm{M}, \mathrm{N}$ ), type 5 (Fig. 4R) and type 9 radulae (Fig. 4S) appear to be more phylogenetically restricted, occurring, respectively, in the two Granulina species, the Protoginella-Mesoginella cluster in the MM1 subclade and the Hydroginella cluster in the MM1 subclade. None of the marginellids examined had radula with odontophoral hoods or with signs of wear. None of the dissected members of the MM2 and MM3 subclades possessed a radula. 
Within the 'Main Cystiscidae' clade, the generic names Cystiscus and Crithe can provisionally be used for the lineages that constitute the MC1 subclade. Similarly, the generic name Pachybathron can be used for the MC5 subclade. In addition, a specimen of the type species of Gibberula, Gibberula zonata Swainson, 1840 (= Volvaria oryza Lamarck, 1822), was successfully sequenced for five genes and, based on its placement, we can unequivocally assign the name Gibberula to the MC4 subclade of our Main Cystiscidae clade. The remaining species in the Main Cystiscidae clade, which are all from the IWP and the Caribbean, were initially assigned to Gibberula. Our phylogenetic data indicate that these should be assigned elsewhere. Of these taxa, 'G.' colombiana can confidently be reclassified in Pachybathron. Neither of the two sequenced species provisionally identified as Persicula (but shown not to be related to one another) provides grounds for a confident attribution of the name Persicula to either the MC2 or MC3 subclades of the Main Cystiscidae clade. So, to ascertain the proper application of names to these clusters, the type species of Persicula should be sequenced, as well as species of the Caribbean genus Osvaldoginella.

Based on the inclusion of its type species in our molecular analyses, the name Prunum can be applied unequivocally to the MM4 subclade of the 'Main Marginellidae' clade. Nevertheless, until the type species of Volvarina and Hyalina are sequenced and their relationships to Prunum established, the scope and status of all three of these names remains uncertain. Our analyses showed Volvarina to be paraphyletic. We note the substantial morphological variation that has been reported for this genus, eight subgenera having been proposed, largely on the basis of radula morphology (Ortea, 2014; Ortea et al., 2019). Clearly, the relationships between the nominal taxa Volvarina, Prunum and Hyalina require further investigation. Particular efforts are needed to assess the validity and rank of the divisions proposed for Volvarina. the MM3 subclade, and the Caribbean Marginella cloveri - in the MM2 subclade. Neither the type species of Marginella (M. glabella Linnaeus, 1758) nor of Glabella (G. faba (Linnaeus, 1758)) were included in the present analysis; both of these genera are from relatively shallow water in the East Atlantic, as are some of the species in the MM3 subclade (Fig. 2). The distinction between Marginella and Glabella is based on the presence of axial ribs and a 
denticulate outer lip in Glabella and lack of these characters in Marginella (Coovert \& Coovert, 1995). Our analyses, however, show that species belonging to these genera are intermixed in the MM3 subclade and so we apply the older name Marginella to the MM3 subclade as a whole. The recent subdivision by Veldsman (2017) of Marginella into numerous 'subgenera' also needs to be further investigated using DNA sequence data.

The genus Dentimargo appears to be one of the most problematic taxa among marginelliforms. Species that were assigned to this genus are split between the MM1 and MM2 subclades, with more in the latter. These results show that the shell characters treated by Coovert \& Coovert (1995) as being diagnostic for Dentimargo (type species Marginella dentifera Lamarck, 1803 from the French Eocene) are inadequate. Coovert \& Coovert (1995: 76) stated that the posterior denticle was "distinctly stronger than the others", but this character is highly variable and applies equally to species in both the MM1 and MM2 subclades. The "spire medium to tall, shell usually narrowly biconic" seems better to suit species in the MM1 subclade, such as those represented by specimens MNHN-IM-2013-45652 and MNHN-IM-201345628 (Fig. 2). Although Coovert \& Coovert (1995) treated Dentimargo as a genus with radulaless species, this character can of course not be examined in the type species, which is a fossil. In fact in our study the species that possess more elongate shells and are included in the clade MM1 actually do have a radula. Therefore, the name Dentimargo cannot be applied to either the MM1 or MM2 subclades.

The Caribbean Eratoidea cf. hematita (Kiener, 1834), which is a member of the MM2 subclade, appears to be morphologically similar to the type species of the genus Eratoidea, $E$. margarita (Kiener, 1834), also from the Caribbean region. Thus, the name Eratoidea Weinkauff, 1879 can be more or less confidently applied to this clade and, in this case, would have a priority over the later name Dentimargo Cossmann, 1899. Likewise, Serrata tuii is conchologically similar to the type species of Serrata, S. serrata and, thus, if applied to the MM1 subclade, the name Serrata Jousseaume, 1875 would have priority over Dentimargo. However, as the type species of Eratoidea and Serrata have not been sequenced in the present study, we refrain from applying these names to the clades in question. Our analysis strongly suggests that if the name Dentimargo is to be used in the context of extant species, the scope of its application should be greatly modified and the genus reviewed in depth. 
The application of the names Mesoginella, Protoginella and Hydroginella to the relevant clusters within the MM1 subclade is straightforward, as is the use of Closia for the pair of species that constitute the sister group of the Volvarina-Hyalina-Prunum cluster.

\section{Family-level classification of marginelliform gastropods}

Our phylogenetic analyses suggest that the three subfamilies currently recognized for the Marginellidae (Marginellinae, Marginelloninae and Granulininae) do not together constitute an exclusive clade (i.e. one containing only these three groups). We obtained strong support for the sister-group relationship between Marginellona gigas (Marginelloninae) and all other marginelliforms. We also found the position of Granulina in the marginelliform part of the tree to be unstable (likely due to long branch attraction); a discussion of the relationships of Granulina to other marginelliforms would be premature at this point, but the distinctiveness of this lineage is nevertheless obvious. On the basis of these results, we elevate Marginelloninae to family rank and follow Boyer (2017) in elevating Granulininae to family rank also. We thereby restrict the family Marginellidae to the the Main Marginellidae clade of our phylogenetic trees.

Following on from the elevation of the former subfamilies of Marginellidae to family rank, we elevate the three tribes currently recognized for the Marginellinae (Marginellini, Prunini and Austroginellini) to subfamily rank. We propose that the the name Marginellinae be applied to the clade uniting the MM2 and MM3 subclades, which comprises radula-less species of Marginella, Dentimargo and Eratoidea. The name Pruninae is applied to the MM4 subclade, which consists of the Closia lineage and species of Prunum, Volvarina and Hyalina. Finally, on the basis of similar radula morphology, we use the name Austroginellinae for the MM1 subclade, which includes the genera Mesoginella and Protoginella. These two genera are characterized by Coovert \& Coovert's (1995) type 5 radula; a strikingly similar radula has been illustrated by Ponder \& Taylor (1992) for Austroginella (not included in our study).

Deep-level relationships within the Cystiscidae (traditionally comprising the subfamilies Cystiscinae, Persiculinae and Plesiocystiscinae) were not resolved. Since we cannot unequivocally rule out the monophyly of the Cystiscidae, we retain the use of this family-level name in its traditional sense. With the exception of Canalispira (all species of this genus constituted a maximally supported clade), the members of the genera formerly included in Cystiscinae and Persiculinae formed part of the MC1 subclade. The lack of resolution of 
relationships within this subclade makes delineating the limits of the Cystiscinae and Persiculinae a difficult task. Therefore, we favour designating the MC1 subclade, in its entirety, a single subfamily, the Cystiscinae. The subfamily-level systematics of the Cystiscidae should be revised to account for the divergent positions of Plesiocystiscus (treated by Coovert \& Coovert, 1995, as a distinct subfamily, the Plesiocystiscinae) and Canalispira (see below). We therefore propose three subfamilies for the Cystiscidae-Cystiscinae, Plesiocystiscinae and Canalispirinae new subfamily.

On the basis of the molecular and morphological data presented above, we revise the Bouchet et al.'s (2017) classification of the marginelliforms as follows:

\title{
Superfamily VOLUTOIDEA Rafinesque, 1815
}

Family MARGINELLONIDAE Coan, 1965

Genera Marginellona Martens, 1904; Afrivoluta Tomlin, 1947; Tateshia Kosuge, 1986

Family CYSTISCIDAE Stimpson, 1865

Subfamily CYSTISCINAE Stimpson, 1865

Genera Cystiscus Stimpson, 1865; Crithe Gould, 1860; Extra Jousseaume, 1894; Gibberula Swainson, 1840; Inbiocystiscus Ortea \& Espinosa, 2001; Intelcystiscus Ortea \& Espinosa, 2001; Pachybathron Gaskoin, 1853; Persicula Schumacher, 1817; Ticocystiscus Espinosa \& Ortea, 2002; Ticofurcilla Espinosa \& Ortea, 2002; ? †Marginocystiscus Landau, C. M. Silva \& Heitz, 2016.

\author{
Genus Plesiocystiscus G. A. Coovert \& H. K. Coovert, 1995.
}

Subfamily PLESIOCYSTISCINAE G. A. Coovert \& H. K. Coovert, 1995 
Diagnosis (adapted from Coovert \& Coovert, 1995): Shell minute to medium sized, white, unsculptured, rarely with faint pattern, cylindrical-biconic to obovate or obconic. Sutures impressed to deeply channeled. Aperture with deeply channeled posterior notch; siphonal notch absent. Outer apertural lip thickened, smooth or lirate; external varix absent. Columella bearing 3-6 plications and weaker parietal lirae. Tentacles absent; siphon not visible; foot split anteromedially, covering external shell surface anterolaterally. Radula uniseriate, composed of horseshoe-shaped rachidians, bearing 7 strong triangular cusps.

Genera Granulina Jousseaume, 1888; Granulinella Boyer, 2017; Granulinopsis Boyer, 2017; Marginellopsis Bavay, 1911; Paolaura Smriglio \& Mariottini, 2001; Pugnus Hedley, 1896; †Hiwia Marwick, 1931.

Genera Marginella Lamarck, 1799; Eratoidea Weinkauff, 1879; ?Gibbacousteau Espinosa \&

Ortea, 2013; ?Dentimargo Cossmann, 1899; ? +Stazzania Sacco, 1890.

Genera Austroginella Laseron, 1957; Alaginella Laseron, 1957; Hydroginella Laseron, 1957; Mesoginella Laseron, 1957; Ovaginella Laseron, 1957; Protoginella Laseron, 1957; Serrata Jousseaume, 1875; ?Caribeginella Espinosa \& Ortea, 1998; ?Marigordiella Espinosa \& Ortea, 500 2010.

501 
504 Genera Prunum Herrmannsen, 1852; Balanetta Jousseaume, 1875; Bullata Jousseaume, 1875;

505 Closia Gray, 1857; Cryptospira Hinds, 1844; Hyalina Schumacher, 1817; Mirpurina Ortea, Moro

506 \& Espinosa, 2019; Rivomarginella Brandt, 1968; Volvarina Hinds, 1844.

507

Marginelliform branch in the neogastropod tree of life

Our results provide the first molecular phylogenetic data for marginelliform neogastropods.

Neither the Marginellidae nor the Cystiscidae, as currently conceived, were found to be monophyletic. Deep-level marginilliform relationships were not resolved, but this does not completely rule out the potential monophyly of Cystiscidae. The Marginellidae, in contrast, were clearly shown to be paraphyletic: Marginellona gigas shows no sisiter-group relationship to the Main Marginellidae clade and the placement of Granulininae remains unresolved. Our analyses demonstrated that the marginelliform gastropods as a whole are monophyletic and that, as hypothesized on the basis of morphological similarities (Ponder, 1970, 1973), they are sister to the family Volutidae. The basal split between Marginellona and the other marginelliform taxa is reflected in the morphology of Marginellona gigas; this taxon has some typical marginellid characters, as well as others that are regarded as plesiomorphic for the Neogastropoda as a whole and are not recorded in other marginelliforms (Harasewych \& Kantor, 1991). The anatomy of the marginelliform foregut is known in detail and the characters shared by Marginellona and other marginellids include the uniseriate comb-like radula within a buccal pouch (Fretter, 1976; Ponder, 1970; Harasewych \& Kantor, 1991; Coovert \& Coovert, 1995).

The pattern of branching of the marginelliform lineages in our trees contradicts the hypothesis of Coovert (1989) and Coovert \& Coovert (1995) that the Cystiscidae are the sister lineage of all other marginelliforms. The strongest evidence for this hypothesis is the fundamentally different radula morphology of the Marginellidae and Marginellona, on the one hand, and of the Cystiscidae, on the other. Our examinations showed that the Marginellidae and Marginellona possess a buccal pouch, while cystiscid radulae have large, firm, paired odontophoral hoods, and retain plesiomorphic morphology with three teeth in each row in Plesiocystiscus. Although the distinction drawn by Coovert \& Coovert (1995) does hold overall, the difference in radula morphology does not correspond to the two reciprocally monophyletic marginellid and cystiscid lineages. Both marginellid and cystiscid radulae have apomorphic 
features, and so any attempt to trace the history of morphological change from one type of radula to the other (e.g. from the radulae of cystiscids to the radula of Marginellona) would be problematic. However, if we look for the homology of cystiscid odontophoral hoods, we find that they could be derived from the marginal cuticular flanges of an ancestral marginellid-type radulae (the membranaceous folds persist, for example, in type 6 radulae). Coovert $\&$ Coovert (1995) considered that these hoods and flanges were fundamentally different, but we argue that the quantitative differences that they emphasized do not preclude the possibility that these structures are, in fact, homologous. The profound transformation of the radula in the ancestor of modern cystiscids could have been driven by selective pressures associated with the evolution of a novel feeding strategy, such as feeding on hard-shelled prey. The presence of a common set of radula features across cystiscids supports a single origin of the Cystiscidae and, given that our trees were only partly resolved, this is the scenario we have reflected in our classification. The disappearance of the buccal pouch can most plausibly be explained by paedomorphosis, that is a shortened postembryonic development leading to the conservation of ancestral features in adult morphology. The same mechanism can be evoked to explain the presence of a triseriate radula in Plesiocystiscus vs uniseriate radulae in all other marginelliforms except Tateshia (see below). The evolution of cystiscids has clearly involved a progressive reduction in adult size, consistent with a paedomorphic origin of this taxon. uniseriate radulae (although of different morphology) are also typical for the Cancellariidae and Volutomitridae. Furthermore, members of these families possess distinct columellar plaits (a character also found in other neogastropod lineages). Relationships among the marginelliforms, Volutidae, Volumitridae and Cancellariidae are controversial and poorly understood, and these taxa are inadequately represented in published phylogenies. Cunha et al. (2009) and Oliverio \& Modica (2010) showed the Cancellariidae as the sister group of other neogastropods and the former study suggested paraphyly of the Neogastropoda. A more recent topology (Fedosov et al., 2015) conflicts with this, showing the Cancellariidae and Volutidae as sister taxa, and the Volutomitridae branch clustering with the costellariid and ptychatractid lineages. A recent phylogenomic analysis of the Conoidea (Abdelkrim et al., 2018) provided additional insights into the early radiation of the Neogastropoda, placing the Cancellariidae, Volutidae and Volutomitridae as three early and independent lineages. 
Radula types, diets and feeding biology of Marginellidae and Cystiscidae

Our morphological data are fragmentary and so a formal analysis of radula evolution in the marginelliforms was not possible. Nonetheless, observations made in the course of this study contradict those of Coovert \& Coovert (1995). These authors described two separate radula types, 'type 6' (characteristic of the Pruninae) and 'modified type 6' (found in the genus Serrata), interpreting the latter as the derived state (Fig. 40). However, in our trees this 'modified type 6' radula appears to be present in several distantly related lineages originating from splits deep within the Marginellidae radiation. This suggests that this character state is the ancestral morphology of the Marginellidae, as circumscribed in our study. Our phylogenetic data suggest that the true 'type 6' radula of Coovert \& Coovert (1995) (Fig. 4P), which is found only in the Volvarina-Prunum-Hyalina clade (MM4 subclade), is the derived state. The available data on the feeding of the Pruninae sensu stricto (all of the MM4 subclade except Closia) suggests that they pry open small bivalves (Winner, 1989); the pits present on the radula teeth of most species of Prunum and Volvarina (Coovert, 1989; Fig. 4P), apparently enhance the capacity of the teeth to interlock and likely prevent radula distortions in the lateral plane. More detailed observations of feeding are needed, however, to understand the links between radula morphology and function.

Whereas the ancestral type 6 radula gave rise to the radulae of Prunum and Volvarina in the MM4 subclade, in the MM1 subclade (i.e. in Mesoginella and Protoginella; Fig. 4R) it has been transformed into the type 5 radula. Ponder \& Taylor (1992) demonstrated the ability of Austroginella johnstoni (Petterd, 1884) and A. muscaria (Lamarck, 1822) to drill bivalve shells. Both of these species possess a type 5 radula (Ponder \& Taylor, 1992), as well as a convoluted tubular midgut gland, which is similar to the venom gland of the Conoidea and is equipped with a ventral duct bypassing the valve of Leiblein. Based on this morphology of the midgut gland, Ponder \& Taylor (1992) suggested that shell drilling in these species is complemented by the use of a toxic secretion of this gland to subdue prey. The fact that a type 5 radula is present in both the Mesoginella and Protoginella groups in the MM1 subclade suggests that it was also present in their common ancestor, and so have also been present in the ancestor of Hydroginella. It follows from this that a duct of Leiblein, similar in morphology to the one described in A. johnstoni (Ponder \& Taylor, 1992), may also have been present in the ancestor of Hydroginella. Species of Hydroginella are peculiar not only because of their unusual type 9 radula (composed of a few, very thin teeth; Fig. 4 S), but also because they parasitize sleeping 
fish, by sucking the blood of their prey (Bouchet, 1989; Bouchet \& Perrine, 1996). Sucking blood of large and usually highly mobile prey requires certain biochemical adaptations to both narcotize the prey and prevent blood coagulation. The adaptations for feeding by blood sucking have been described in detail for another neogastropod, the 'vampire snail' Cumia reticulata (Blainville, 1829), which belongs to the Colubrariidae (Modica et al., 2015; Gerdol et al., 2018). Hydroginella species are characterized by a highly modified tubular gland of Leiblein, the legacy of their shell-boring ancestors; this adaptation may have been a key prerequisite for the evolution of blood sucking in this group. Interestingly, Hydroginella is not the only marginellid parasitizing fish. A similar feeding biology was described by Kosuge (1986) for Tateshia yadai Kosuge, 1986, multiple specimens of which were found attached to the pectoral fins of the scorpaenid fish Helicolenus hilgendorfi at depths of about $300 \mathrm{~m}$. Kosuge (1986) originally placed Tateshia in Olividae on the basis of its triseriate radula. However, the genus was reassigned to the Marginellidae by Bouchet (1989), who regarded the type of radula (comprising rachidian as well as laterals) found in Tateshia to be an underived ancestral feature, and the evidence that Tateshia originated from rachiglossate predecessors. The phylogenetic relationships of this enigmatic gastropod require further investigation, but this is hampered at present by the exceptional rarity of Tateshia.

The type 3 radula (Figs 4E-M) is most widespread in the cystiscid lineages, including the Gibberula-Persicula-Pachybathron subclade and Canalispira. This type of radula usually has bow- or horseshoe-shaped multicuspidate teeth, each bearing a strong central cusp. The uniseriate radulae of the nematoglossan type is often considered as an adaptation to suctorial feeding; the extremely elongated central cusps pierce the integument of prey, while the lateral cusps facilitate interlocking of successive teeth, rendering the radula more rigid and possibly more resistant to lateral deformation (Petit \& Harasewych, 1986; Modica et al., 2011). Published observations on Cystiscus species feeding on bryozoans (Coleman, 1975) suggest that the radulae of marginelliforms may function in a similar manner. However, of particular interest is the clear signs of wear that were observed in nearly all the examined cystiscid radulae (Figs 4B, G, I, L). This wear is most likely the result of mechanical abrasion, which suggests that cystiscid radulae come into contact with tough substrata, such as the frontal membrane or the cryptocyst of colonial bryozoans. The specialization for feeding on sedentary prey with thick integument may explain the origin of the cystiscid type of radula. The firm odontophoral hoods presumably provide additional mechanical support for the radula by leveraging the pressure on 
631 the odontophore cartilage. The rapid wearing-down of the radula implies a need for prompt

632 replacement of teeth and an accelerated turnover. In this context, the very long cystiscid

633 radulae, consisting of over 100 teeth, and the occurrence of nascent teeth in groups of five or

634 six (Coovert \& Coovert, 1995), can be seen as adaptations to counterbalance the rapid abrasion 635 of the teeth.

636 
The material used in this study originates from numerous shore-based expeditions and deep sea cruises, conducted respectively by MNHN and Pro-Natura International as part of the Our Planet Reviewed programme, and by MNHN and Institut de Recherche pour le Développement as part of the Tropical Deep-sea Benthos programme. All expeditions operated under the regulations then in force in the countries in question and satisfy the conditions set by the Nagoya Protocol for access to genetic resources. Funders and sponsors include the Total Foundation, Prince Albert II of Monaco Foundation, Stavros Niarchos Foundation, Richard Lounsbery Foundation and the French Ministry of Foreign Affairs. Sampling in Western Australia was arranged by Hugh Morrison, with the support of the Western Australian Museum. We thank Noel Saguil for help with sample collection in the Philippines. The specimens used in this study were obtained in conjunction with a collecting trip of the University of the Philippines, which was supported in part by International Cooperative Biodiversity Group (ICBG grant no. 1U01TW008163). We thank, among others, Virginie Héros, Philippe Maestrati, Pierre Lozouet, Ellen Strong, Laurent Charles and Julien Brisset for their role in the processing of specimens during the expeditions and curation. The photos of live marginelliforms were taken by Laurent Charles (MNHN), Philippe Maestrati (MNHN), and Gustav Paulay (Florida Museum of Natural History). We thank Catherine Rausch (MNHN) and Anna Neretina (IPEE) for access to SEM facilities at MNHN and IEE RAS. We are grateful to Marco Oliverio and Yuri Kantor for their critical comments on the manuscript and to David Reid for his careful and through editing of the final version of the manuscript.This study was largely accomplished during curatorial visits made by the first author to MNHN in 2016-2019. The molecular phylogenetic studies were supported by the Service de Systématique Moléculaire (UMS 2700 CNRS-MNHN), ATM Barcode (PIs Sarah Samadi and Jean-Noël Labat, MNHN), ANR project CONOTAX (grant no. ANR-13-JSV70013-01, PI Nicolas Puillandre) and by a grant from the Russian Science Foundation (RSF 16-1410118, PI Y. Kantor).

\section{REFERENCES}

ABDELKRIM, J., AZNAR-CORMANO, L., FEDOSOV, A., KANTOR, Y., LOZOUET, P., PHUONG, M., ZAHARIAS, P. \& PUILLANDRE, N. 2018. Exon-capture based phylogeny and diversification of the 
667

668

669

670

671

672

673

674

675

676

677

678

679

680

681

682

683 684

685

686

687

688

689

690

691

692

693 694

venomous gastropods (Neogastropoda, Conoidea). Molecular Biology and Evolution, 35: 23552374.

BANDEL, K. 1984 The radulae of Carribbean and other Mesogastropoda and Neogastropoda. Zoologische Verhandelingen, 214: 1-187.

BOUCHET, P. 1989. A marginellid parasitizes sleeping fishes. Bulletins of Marine Science, 45: 7684.

BOUCHET, P. \& PERRINE, D. 1996. More gastropods feeding at night on parrotfishes. Bulletin of Marine Science, 59: 297-301.

BOUCHET, P., ROCROI, J.-P., HAUSDORF, B., KAIM, A., KANO, Y., NÜTZEL, A., PARKHAEV, P., SCHRÖDL, M. \& STRONG, E.E. 2017. Revised classification, nomenclator and typification of gastropod and monoplacophoran families. Malacologia, 61: 1-526.

BOYER, F. 2017. Révision de l'organisation supra-spécifique des gastéropodes granuliniformes. Xenophora Taxonomy, 16: 25-38.

BRIGGS, J.C. \& BOWEN, B.W. 2012. A realignment of marine biogeographic provinces with particular reference to fish distributions. Journal of Biogeography, 39: 12-30.

CLAREMONT, M., REID, D.G. \& WILLIAMS, S.T. 2012 Speciation and dietary specialization in Drupa, a genus of predatory marine snails (Gastropoda: Muricidae). Zoologica scripta, 41: 137-149.

COAN, E. 1965. A proposed reclassification of the family Marginellidae. Veliger, 7: 184-194.

COLEMAN, N. 1975. What shell is that? Paul Hamlyn, Sydney.

COOVERT, G.A. 1989. A literature review and summary of published marginellid radulae. Marginella Marginalia, 7: 1-37.

COOVERT, G.A. \& COOVERT, H.K. 1995. Revision of the supraspecific classification of marginelliform gastropods. Nautilus, 109: 43-110.

CUNHA, R.L., GRANDE, C. \& ZARDOYA, R. 2009. Neogastropod phylogenetic relationships based on entire mitochondrial genomes. BMC Evolutionary Biology, 9: 210.

EDGAR, R.C. 2004. MUSCLE: multiple sequence alignment with high accuracy and high throughput. Nucleic Acids Research, 32: 1792-1797. 
FEDOSOV, A.E., PUILLANDRE, P., KANTOR, Y.I. \& BOUCHET, P., 2015. Phylogeny and systematics of mitriform gastropods (Mollusca: Gastropoda: Neogastropoda). Zoological Journal of the Linnaean Society, 175: 336-359.

FEDOSOV, A.E., PUILLANDRE, N., HERRMANN, M., DGEBUADZE, P. \& BOUCHET, P. 2017. Phylogeny, systematics and evolution of the family Costellariidae (Gastropoda: Neogastropoda). Zoological Journal of the Linnean Society, 179: 541-626.

FEdOSOV, A.E., PUILLANDRE, N., HERRMANN, M., KANTOR, Y.I., OLIVERIO, M., DGEBUADZE, P., MODICA, M.V. \& BOUCHET, P. 2018. The collapse of Mitra: molecular systematics and morphology of the Mitridae (Gastropoda: Neogastropoda). Zoological Journal of the Linnaean Society, 183: 253-337.

FELSENSTEIN, J., 1985. Confidence limits on phylogenies: an approach using the bootstrap. Evolution, 39: 783-791.

FRETTER, V. 1976. The anatomy and feeding of the volutacean prosobranch Volvarina taeniolata Morch. Journal of Molluscan Studies, 42: 327-336.

GALINDO, L.A., PUILLANDRE, N., UTGE, J., LOZOUET, P. \& BOUCHET, P. 2016 The phylogeny and systematics of the Nassariidae revisited (Gastropoda, Buccinoidea). Molecular Phylogenetics and Evolution, 99: 337-353.

GALINDO, L.A., PUILLANDRE, P., STRONG, E.E. \& BOUCHET, P. 2014. Using microwaves to prepare gastropods for DNA Barcoding. Molecular Ecology Resources, 14: 700-705.

GERDOL M., CERVELLI M., OLIVERIO M. \& MODICA M.V. 2018. Piercing fishes: porin expansion and adaptation to hematophagy in the vampire snail Cumia reticulata. Molecular Biology and Evolution, 35: 2654-2668. HALL, T.A. 1999. BioEdit: a user-friendly biological sequence alignment editor and analysis program for Windows 95/98/NT. Nucleic Acids Symposium Series, 41: 95-98.

HARASEWYCH, M.G. \& KANTOR, Yu. I. 1991. Rediscovery of Marginellona gigas (Martens, 1904). with notes on the anatomy and systematic position of the subfamily Marginelloninae

721 (Gastropoda: Marginellidae). Nemouria, 37: 1-19. 
KALYAANAMOORTHY, S., MINH, B.Q., WONG, T.K.F., VON HAESELER, A. \& JERMIIN, L.S. 2017. ModelFinder: fast model selection for accurate phylogenetic estimates. Nature Methods, 14: 587-589.

KANTOR, Y.I. 2002 Morphological prerequisites for understanding neogastropod phylogeny. Bollettino Malacologico, Supplement 4: 161-174.

KANTOR, Y.L., FEDOSOV, A., PUILLANDRE, N., BONILLO, C. \& BOUCHET, P. 2017. Returning to the roots: morphology, molecular phylogeny and classification of the Olivoidea (Gastropoda: Neogastropoda). Zoological Journal of the Linnaean Society, 180: 493-541.

KANTOR, Y.I., FEDOSOV, A.E., SNYDER, M.A. \& BOUCHET, P. 2018. Pseudolatirus Bellardi, 1884 revisited, with the description of two new genera and five new species (Neogastropoda: Fasciolariidae). European Journal of Taxonomy, 433: 1-57.

LANFEAR, R., FRANDSEN, P.B., WRIGHT, A.M., SENFELD, T. \& CALCOTT, B. 2016. PartitionFinder 2: new methods for selecting partitioned models of evolution for molecular and morphological phylogenetic analyses. Molecular Biology and Evolution, 34:772-773

LASERON, C. F. 1957. A new classification of the Australian Marginellidae, with a review of species from the Solanderian and Dampierian zoogeographical provinces. Australian Journal of Marine and Freshwater Research, 8: 274-311.

MILLER, M.A., PFEIFFER, W. \& SCHWARTZ, T. 2010. Creating the CIPRES science gateway for inference of large phylogenetic trees. In: Proceedings of the Gateway Computing Environments Workshop (GCE), pp. 1-8. New Orleans.MODICA, M.V., LOMBARDO, F., FRANCHINI, P. \& OLIVERIO, M. 2015. The venomous cocktail of the vampire snail Colubraria reticulata (Mollusca, Gastropoda). BMC Genomics, 441: 1-21.

MODICA, M.V., BOUCHET, P., CRUAUD, C., UTGE, J. \& OLIVERIO, M. 2011. Molecular phylogeny of the nutmeg shells (Neogastropoda, Cancellariidae). Molecular Phylogenetics and Evolution, 59: 685-697.

MOLLUSCABASE. 2019. MolluscaBase. http://www.molluscabase.org Accessed on 30 June 2019.

NGUYEN, L.T., SCHMIDT, H.A., von HAESELER, A., \& MINH, B.Q. 2014. IQ-TREE: a fast and effective stochastic algorithm for estimating maximum-likelihood phylogenies. Molecular Biology and Evolution, 32: 268-274. 
OLIVERIO, M. \& MODICA, M.V. 2010. Relationships of the haematophagous marine snail Colubraria (Rachiglossa, Colubrariidae), within the neogastropod phylogenetic framework. Zoological Journal of the Linnean Society, 158: 779-800.

ORTEA, J. 2014. Como integrar Ciencia y Naturaleza, descripción de nuevas especies del género Volvarina Hinds, 1844 (Mollusca: Marginellidae) de la isla de Guadalupe y sus islotes satélites (Antillas Menores, Mar Caribe), nombradas en honor de 30 mujeres distinguidas con el Premio L'Oreal-Unesco. Revista Academia Canaria de Ciencias, 26: 129-188.

ORTEA, J. 2016. Descripción de una segunda especie del género Ticofurcilla Espinosa \& Ortea, 2002 (Mollusca: Cystiscidae) colectada en Martinica, Antillas Menores. Revista de la Academia Canaria de Ciencias, 28: 195-200.

ORTEA, J., MORO, L. \& ESPINOSA, J. 2019. Otra visión de la estructura del género Volvarina Hinds, 1844 (Mollusca: Marginellidae) en las islas de Cabo Verde. I, el caso de Volvarina taeniata (Sowerby, 1846). Avicennia, 24: 9-20.

PETIT, R.E. \& HARASEWYCH, M.G. 1986. New Philippine Cancellariidae (Gastropoda: Cancellariacea), with notes on the fine structure and function of the nematoglossan radula. Veliger, 28: 436-443.

PONDER, W.F. 1970. Some aspects of the morphology of four species of the neogastropod family Marginellidae with a discussion on the evolution of the toxoglossan poison gland. Journal of Malacological Society of Australia, 2: 55-81.

PONDER, W.F. 1973. The origin and evolution of the Neogastropoda. Malacologia, 12: 295-338. PONDER, W.F. \& TAYLOR, J.D. 1992. Predatory shell drilling by two species of Austroginella (Gastropoda: Marginellidae). Journal of Zoology, 228: 317-328.

PUILLANDRE, P., LAMBERT, A., BROUILLET, S. \& ACHAZ, G. 2012. ABGD, automatic barcode gap discovery for primary species delimitation. Molecular Ecology, 21: 1864-1877.

PUILLANDRE, N., MODICA, M.V., ZHANG, Y., SIROVICH, L., BOISSELIER, M.C., CRUAUD, C., HOLFORD, M. \& SAMADI, S. 2012. Large scale species delimitation method for hyperdiverse groups. Molecular Ecology, 21: 2671-2691.

RAMBAUT, A., SUCHARD, M.A., XIE, D. \& DRUMMOND, A.J., 2014. Tracer v. 1.4. Available at http://beast.bio.ed.ac.uk/Tracer 
SOUZA, Jr. P. J. S. 2007. Análise cladística da família Marginellidae (Mollusca, Gastropoda) baseada em morfologia comparada. PhD thesis. Instituto de Biociências da Universidade de São Paulo. São Paulo. Brazil.

SOUZA, Jr. P. J. S. \& SIMONE, L. R. L. 2019 Cladistic analysis of the family Marginellidae (Mollusca, Gastropoda) based on phenotypic features. Zootaxa, 4648: 201-240.

VELDSMAN, S.G. 2017. Taxonomic reclassification of the genus Marginella Lamarck, 1799 and description of new subgenera (Neogastropoda: Marginellidae). Visaya, Supplement 9: 5-46. WENZ, W. 1938-1944. Gastropoda. Teil 1, Allgemeiner Teil und Prosobranchia. In: Handbuch der Paläozoologie, Band 6, Gastropoda (O.H. Schindewolf, ed.), pp. 1-1639. Gebrüer Bornträger, Berlin.

WINNER, B. 1989. Marginella (Prunum) apicina-eating and egg producing habits. Hawaiian Shell News, 37: 31.

ZOU, S., Li, Q. \& KONG, L. 2011. Additional gene data and increased sampling give new insights into the phylogenetic relationships of Neogastropoda, within the caenogastropod phylogenetic framework. Molecular Phylogenetics and Evolution, 61: 425-435.

\section{FIGURE CAPTIONS}

Figure 1. Live marginelliform gastropods (not shown to scale). A. Ticofurcilla mariolysae

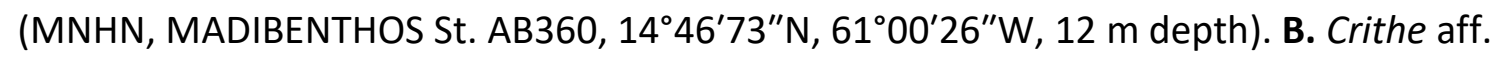
marianoi (MNHN-IM-2013-2989, PAPUA NIUGINI St. PB18, 0506.3'S, 14549.1'E, $26 \mathrm{~m}$ depth). C. Cystiscus sp. (MNHN- IM-2013-3692, PAPUA NIUGINI St. PB21 5¹'26.89"S, 145²4'2"E, 5 m depth). D. 'Gibberula' sp. (MNHN-IM-2013-4208, PAPUA NIUGINI St. PB26, 0459.1'S, $145^{\circ} 47.7^{\prime} \mathrm{E}, 22 \mathrm{~m}$ depth). E. 'Gibberula' aff. moscatellii (MNHN-IM-2013-56965, ILES DU SALUT St. SS01, $05^{\circ} 16.9^{\prime} \mathrm{N}, 52^{\circ} 35.1^{\prime} \mathrm{W}, 8 \mathrm{~m}$ depth). F. Canalispira sp. (MNHN-IM-2013-1838, PAPUA NIUGINI St. PS09, 05¹2.3'S, 14548.8'E, 8-10 m depth). G. Marginella festiva (MNHN-IM-201343709, Dakar'09 St. 09, $14^{\circ} 39.9^{\prime} \mathrm{N}, 17^{\circ} 24.0^{\prime} \mathrm{W}, 7 \mathrm{~m}$ depth). H. Eratoidea cf. hematita (MNHNIM-2013-60596, KARUBENTHOS 2 St. DW4559, 16²4.5'N, 6051.8'W, 72-111 m depth). I. 'Dentimargo' sp. (MNHN-IM-2013-3409, PAPUA NIUGINI St. PS15, 55'47.4"S, 14548'11.7"E, 12 m depth). J. 'Marginella' cloveri (MNHN-IM-2013-56775, GUYANE 2014 St. CP4402, 6¹8'N, 52 ${ }^{\circ} 13.3^{\prime} \mathrm{W}, 95-97 \mathrm{~m}$ depth). K. Volvarina aff. avena (MNHN-IM-2013-60828, KARUBENTHOS 2 
St. DW4579, $16^{\circ} 21^{\prime} \mathrm{N}, 60^{\circ} 54^{\prime} \mathrm{W}, 228-264 \mathrm{~m}$ depth). L. Granulina sp. (MNHN-IM-2013-1289, PAPUA NIUGINI St. PB06, 0509.9'S, 14550.4'E, 20 m depth).

Figure 2. ML phylogeny of the Neogastropoda showing cystiscid (blue shading) and marginellid (red shading) lineages (tree reconstructed by RaxML). Dark and light shading in the marginelliform part of the tree (Marginellona + 'Main Cysticidae' + Canalispira + Plesiocystiscus + 'Main Marginellidae') indicate provisional boundaries of genus-level taxa. Branch support values are shown in the following sequence: Bayesian posterior probability/\% bootstrap from the RaxML analysis/\% bootstrap from the IQtree analysis. Locality codes: CO, Congo; GA, French Guiana; GU, Guadeloupe; MA, Madagascar; MO, Mozambique; MQ, Martinique; NC, New Caledonia; PH, Philippines; PNG, Papua New Guinea; SE, Senegal; TA, Tasmania; TW, Taiwan; WA, South-Western Australia. Lineages identified to genus level, on the basis that they are represented by or include the type species of that genus, are shown in bold font.

Figure 3. Close up of the marginelliform part of the tree depicted in Figure 1, with images of the shells of most of the sequenced specimens. Generic names in bold and non-bold font correspond, respectively, to genera supported by molecular evidence and those in need of revision. Locality codes as in Figure 2 Colour-coding indicates the major biogeographical regions: IWP, blue; Western Indian Ocean, green; West Africa, yellow; Caribbean, red. Depth is shown by Light (shallow) or dark (deep) shadeing. Boxed numbers indicate the radula type of individuals examined by us, with '!' denoting somewhat deviating radula morphology and '6*' indicating the modified type 6 of Coovert \& Coovert (1995).

Figure 4. Radulae of studied marginelliform specimens. Numbers under the scale bars below the radula images indicate scale units. A, B. Type 1, Plesiocystiscus sp. (MNHN-IM-2013-43724, GUYANE St. CP4380, $6^{\circ} 31^{\prime} \mathrm{N}, 52^{\circ} 27^{\prime} \mathrm{W}, 102-104 \mathrm{~m}$ depth), showing intact (A) and older, worn (B) areas of radula. C, D. Type 2, Cystiscus sp. (MNHN-IM-2013-43726, TASMANIA St. TA44, $41^{\circ} 18.2^{\prime} \mathrm{S}, 148^{\circ} 18.8^{\prime} \mathrm{E}, 3-6 \mathrm{~m}$ depth), showing frontal (C) and lateral (D) views. E. Type 3,

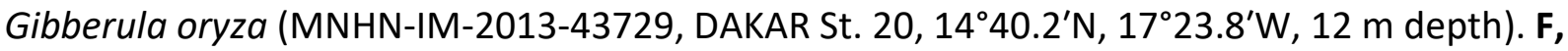
G. Type 3, Gibberula nebulosa (MNHN-IM-2013-68353, KANACONO St. DW4661, 2248'S, $167^{\circ} 07^{\prime} \mathrm{E}, 405-410 \mathrm{~m}$ depth), showing intact (-) and worn, older (G) areas of radula. H, I. Type 3, Canalispira sp. (Oman, Masirah, leg. F. Boyer, 2013), showing intact (H) and worn, older (I) areas of radula. J, K. Type 3, 'Persicula' sp. (Oman, Masirah, leg. Franck Boyer, 2013), showing intact (J) and worn, older (K) areas of radula. L. Type 3, Pachybathron cf. cassidiforme (MNHNIM-2013-61020, KARUBENTHOS2 St.DW4593, $15^{\circ} 56^{\prime} \mathrm{N}, 61^{\circ} 26^{\prime} \mathrm{W}, 133-152 \mathrm{~m}$ depth). M. Type 4, 
845 Granulina liliputana (MNHN-IM-2013-43723 Dakar'09 St. 10, 14³9.8'N, 17²3.9'W, $31 \mathrm{~m}$

846 depth). N. Type 4, Granulina sp. (MNHN-IM-2013-43732, MADEEP St. DW4287, 9¹2'S,

$847153^{\circ} 56^{\prime} \mathrm{E}, 340-375 \mathrm{~m}$ depth). O. 'Modified type 6', 'Dentimargo' sp. (MNHN-IM-2013-45652,

848 MADEEP St. DW4292, 9¹4'S, 153 ${ }^{\circ} 52^{\prime} \mathrm{E}, 530 \mathrm{~m}$ depth). P. Type 6, Prunum prunum (MNHN-IM-

849 2013-57005, GUYANE St. SN08, 517' N, 52³5.1'W, 6m depth). Q. Type 7, Marginellona gigas

850 (MNHN-IM-2013-50159, DongSha St. CP4127, 2046'N, 11608'E, 392-408 m depth). R. Type 5,

851 Mesoginella sp. (MNHN-IM-2013-43731, EXBODI St. DW3785, 22¹5'S; 167¹0'E, 386-387 m). S.

852 Type 9, Hydroginella cf. tridentata (MNHN-IM-2013-43735, WESTERN AUSTRALIA St. WE03,

$853 \quad 33^{\circ} 59.6^{\prime} \mathrm{S} ; 122^{\circ} 13.3^{\prime} \mathrm{E}, 11 \mathrm{~m}$ depth). 


\section{_IM-2013-50202 Calliotectum sp. \\ IM-2009-9486 Volutocorbis sp. IM-2009-7377 Lyria sp. \\ VOLUTIDAE}

IM-2013-44037 Fulgoraria rupestris

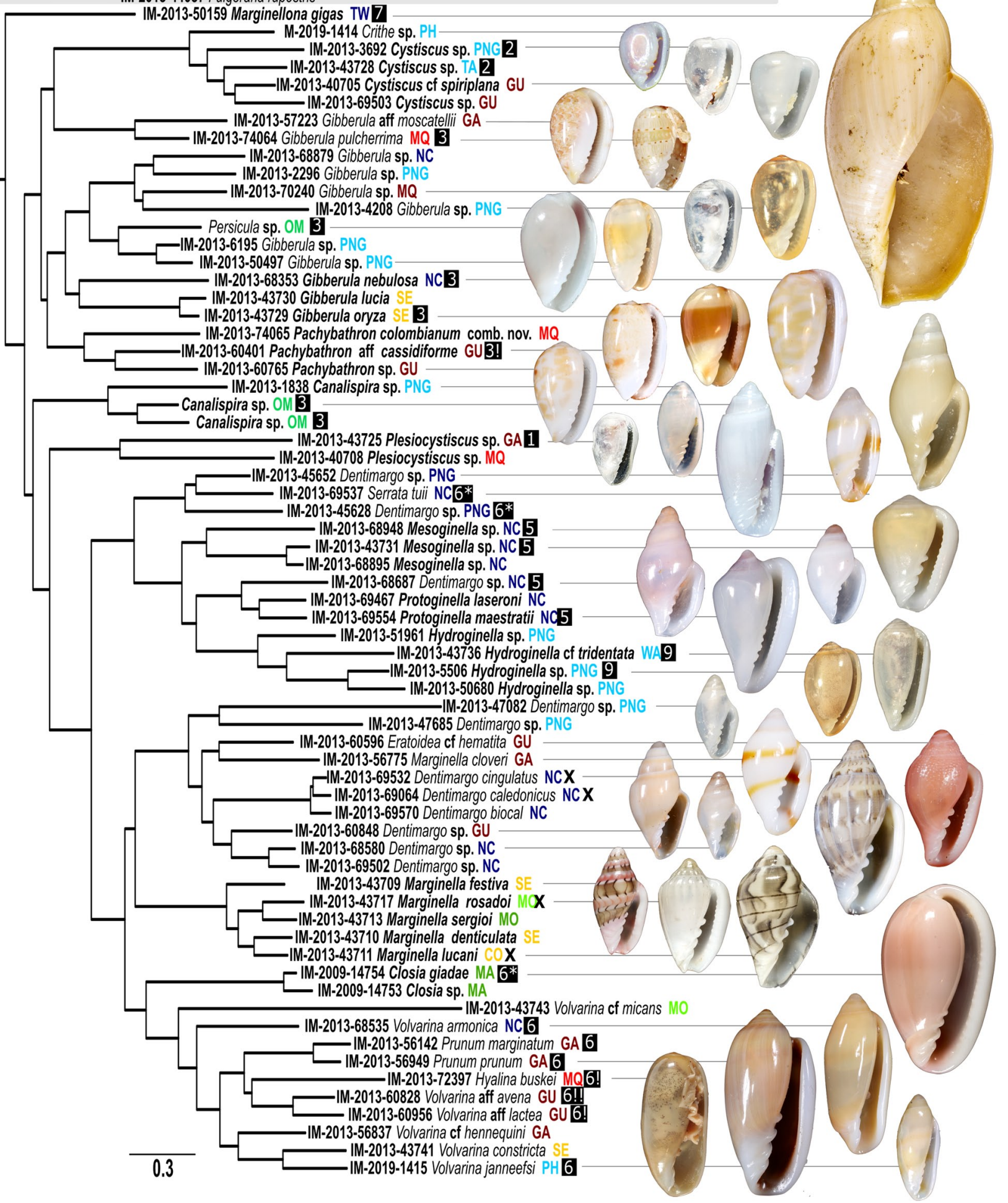



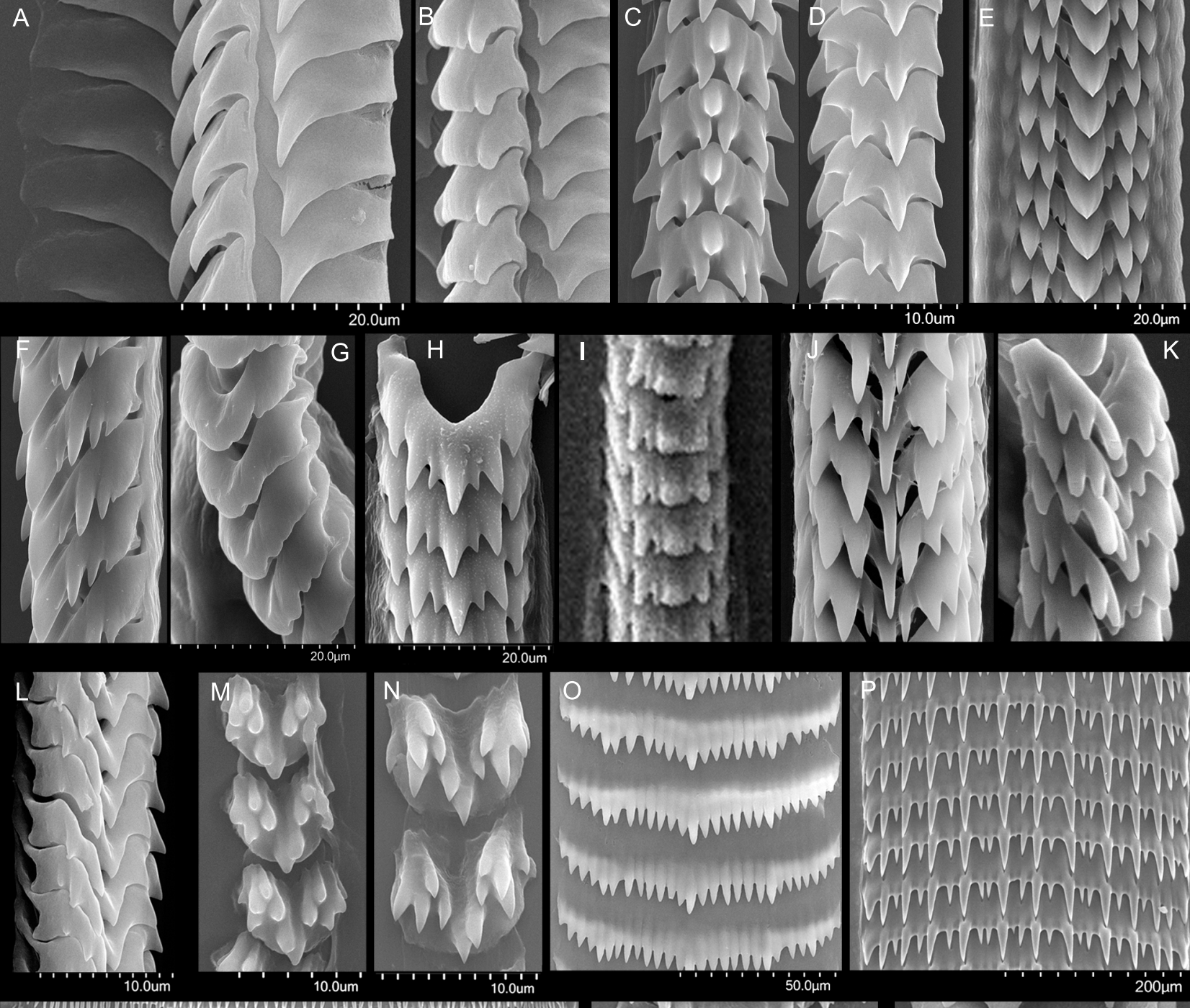

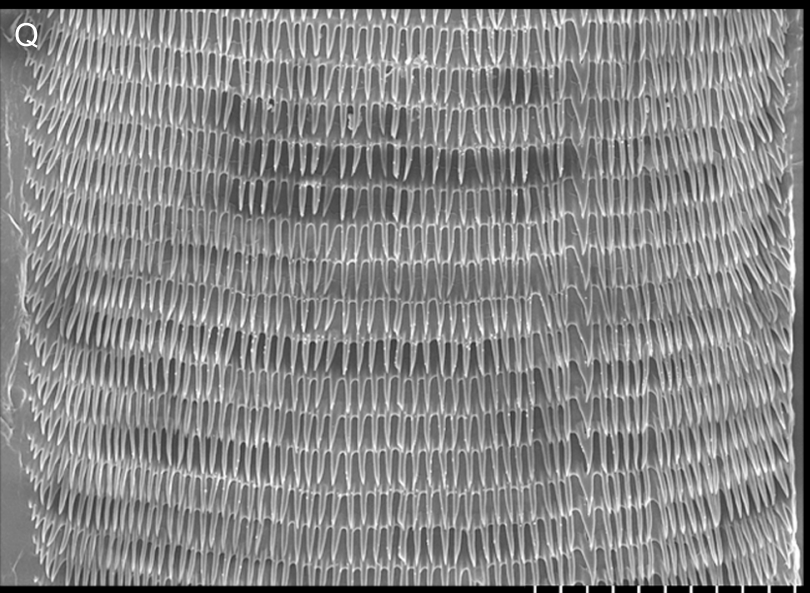

50.0um

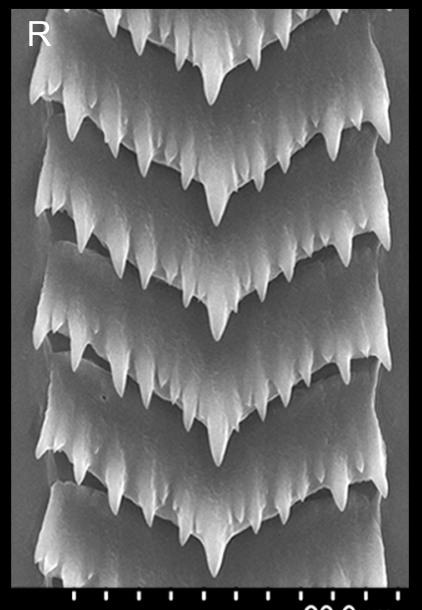

$30.0 u m$

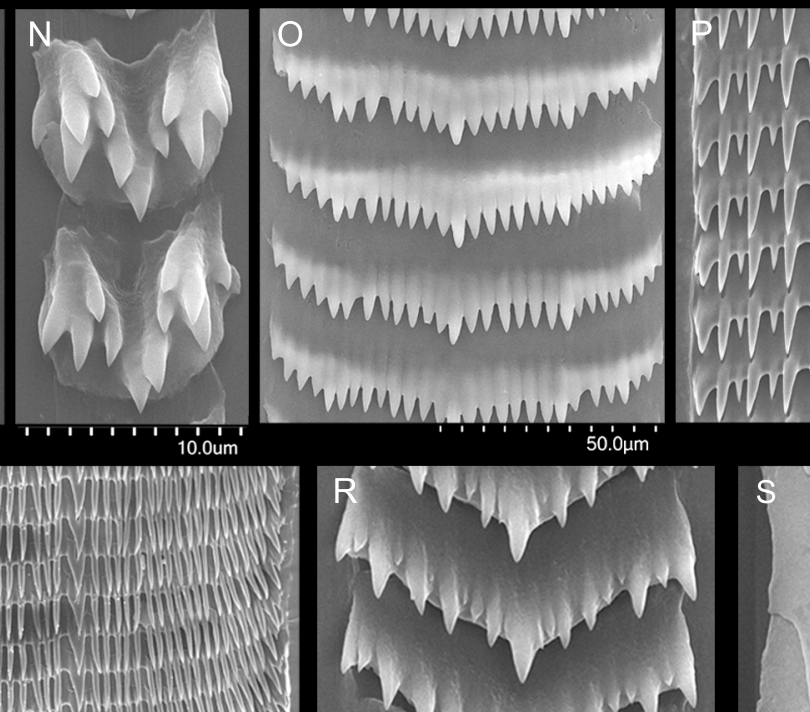

(1)

\$
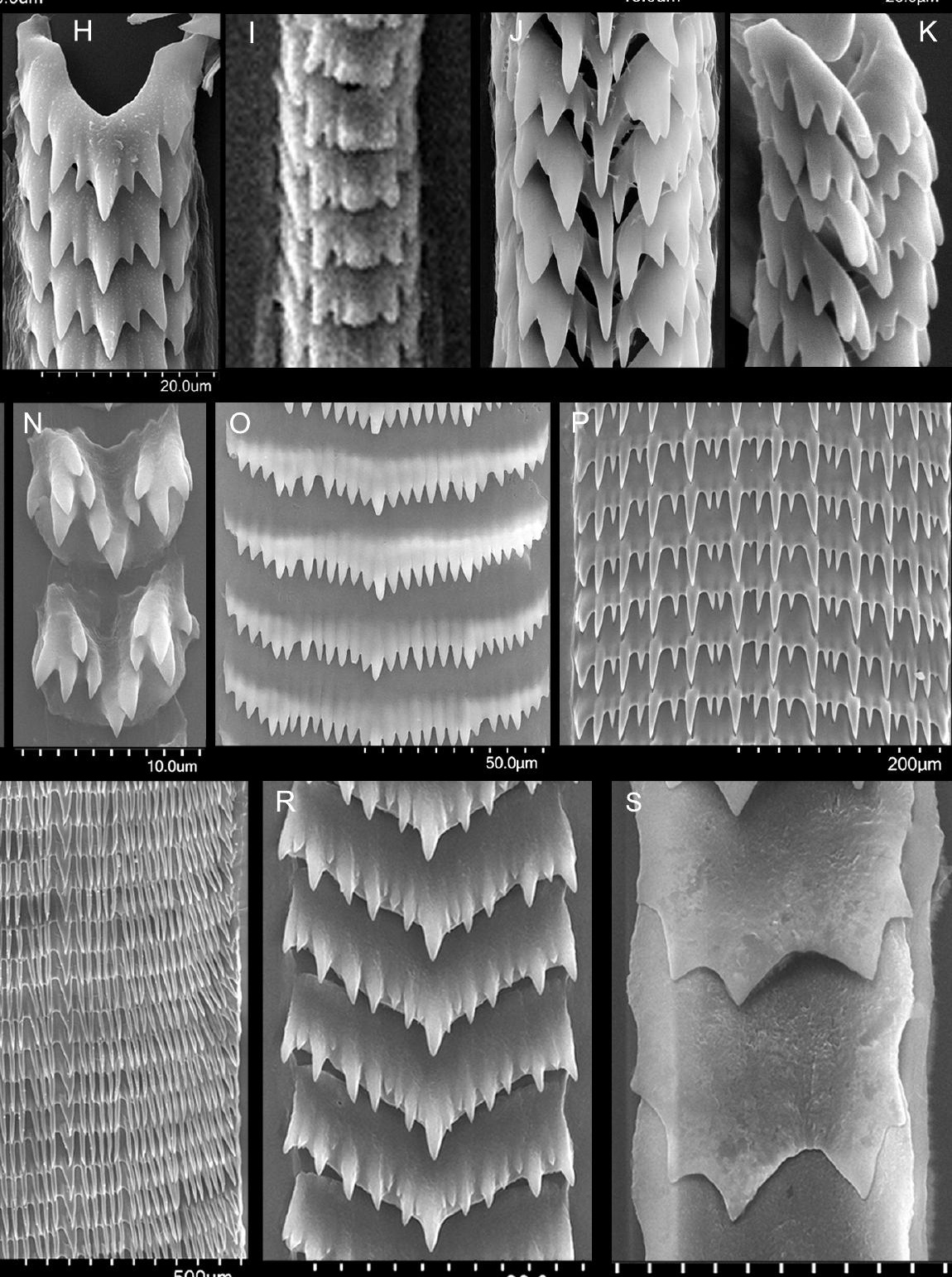

20.0um 
1 Table 1. List of specimens included in molecular phylogenetic analyses, with relevant museum registration numbers, collection data, Barcode of Life 2 Datasystems (BOLD) IDs and details of DNA sequence data available for the five gene regions COI, 16s rRNA, 12S rRNA, H3 and 28S rRNA.

\begin{tabular}{|c|c|c|c|c|c|c|c|c|c|c|c|}
\hline Family & Species & Specimen ID & Expedition & Station & Locality & BOLD & COI & 165 rRNA & 12S rRNA & H3 & $28 \mathrm{~S}$ rRNA \\
\hline \multicolumn{12}{|l|}{ INGROUP } \\
\hline Cystiscidae & Canalispira sp. & $\begin{array}{l}\text { MNHN-IM-2013- } \\
1838\end{array}$ & PAPUA NIUGINI & PS09 & $\begin{array}{l}5^{\circ} 12^{\prime} 20^{\prime \prime} S, 145^{\circ} 48^{\prime} 47^{\prime \prime} \mathrm{E}(8-10 \mathrm{~m} \\
\text { depth) }\end{array}$ & NEOGA1335-19 & 1 & 0 & 1 & 1 & 1 \\
\hline Cystiscidae & Canalispira sp. 2 & FBoyer_C1 & - & - & Oman, Masirah & - & 1 & 1 & 1 & 1 & 1 \\
\hline Cystiscidae & Canalispira sp. 3 & FBoyer_C2 & - & - & Oman, Masirah & - & 1 & 1 & 1 & 1 & 1 \\
\hline Cystiscidae & Persicula sp. & FBoyer_P1 & - & - & Oman, Masirah & - & 0 & 1 & 1 & 1 & 1 \\
\hline Cystiscidae & Crithe sp. & $\begin{array}{l}\text { MNHN-IM-2019- } \\
1414 \\
\text { /Cc-PH-301 }\end{array}$ & - & - & $\begin{array}{l}\text { Philippines, Mactan Is., off Punta- } \\
\text { Engana (Iumun-lumun net) }\end{array}$ & NEOGA1336-19 & 1 & 0 & 1 & 1 & 1 \\
\hline Cystiscidae & Cystiscus sp. & $\begin{array}{l}\text { MNHN-IM-2013- } \\
3692\end{array}$ & PAPUA NIUGINI & PB21 & $5^{\circ} 1^{\prime} 26.9^{\prime \prime S}, 145^{\circ} 48^{\prime} 2^{\prime \prime E}$ (5 m depth) & NEOGA1337-19 & 1 & 0 & 1 & 1 & 1 \\
\hline Cystiscidae & Cystiscus cf. spiriplana & $\begin{array}{l}\text { MNHN-IM-2013- } \\
40705\end{array}$ & KARUBENTHOS 2 & DW4722 & $22^{\circ} 54^{\prime} \mathrm{S}, 167^{\circ} 17^{\prime} \mathrm{E}$ (496-505m depth) & NEOGA1338-19 & 0 & 1 & 1 & 1 & 1 \\
\hline Cystiscidae & Cystiscus aff. spiriplana & $\begin{array}{l}\text { MNHN-IM-2013- } \\
69503\end{array}$ & KARUBENTHOS 2 & DW4722 & $22^{\circ} 54^{\prime} \mathrm{S}, 167^{\circ} 17^{\prime} \mathrm{E}$ (496-505m depth) & NEOGA1339-19 & 1 & 0 & 1 & 1 & 1 \\
\hline Cystiscidae & Cystiscus sp. & $\begin{array}{l}\text { MNHN-IM-2013- } \\
43728\end{array}$ & $\begin{array}{l}\text { MORRISON } \\
\text { AUSTRALIA }\end{array}$ & TA44 & $41^{\circ} 18.2^{\prime} \mathrm{S}, 148^{\circ} 18.8^{\prime} \mathrm{E}$ (3-6 m depth) & NEOGA1340-19 & 0 & 1 & 1 & 1 & 1 \\
\hline Cystiscidae & Pachybathron n. sp. & $\begin{array}{l}\text { MNHN-IM-2013- } \\
60765\end{array}$ & KARUBENTHOS 2 & DW4574 & $\begin{array}{l}16^{\circ} 21^{\prime} 48^{\prime \prime} \mathrm{N}, 60^{\circ} 53^{\prime} 51^{\prime \prime} \mathrm{W}(140-340 \mathrm{~m} \\
\text { depth) }\end{array}$ & NEOGA1341-19 & 1 & 1 & 1 & 1 & 1 \\
\hline Cystiscidae & Gibberula sp. & $\begin{array}{l}\text { MNHN-IM-2013- } \\
70240\end{array}$ & MADIBENTHOS & CP4129 & $14^{\circ} 38^{\prime} 35^{\prime \prime} \mathrm{N}, 61^{\circ} 8^{\prime} 30^{\prime \prime} \mathrm{W}$ (8 m depth) & NEOGA1342-19 & 1 & 0 & 1 & 0 & 1 \\
\hline Cystiscidae & Gibberula lucia & $\begin{array}{l}\text { MNHN-IM-2013- } \\
43730\end{array}$ & Dakar'09 & Stn. 6 & $\begin{array}{l}14^{\circ} 39^{\prime} 48^{\prime \prime N}, 17^{\circ} 29^{\prime} 0^{\prime \prime} \mathrm{W}(14-19 \mathrm{~m} \\
\text { depth) }\end{array}$ & NEOGA1343-19 & 1 & 0 & 1 & 1 & 1 \\
\hline Cystiscidae & Gibberula oryza & $\begin{array}{l}\text { MNHN-IM-2013- } \\
43729\end{array}$ & Dakar'09 & Stn. 4 & $14^{\circ} 40^{\prime} 12^{\prime \prime} \mathrm{N}, 17^{\circ} 23^{\prime} 48^{\prime \prime} \mathrm{W}$ (12 m depth) & NEOGA1344-19 & 1 & 1 & 1 & 1 & 1 \\
\hline Cystiscidae & Gibberula sp. 1 & $\begin{array}{l}\text { MNHN-IM-2013- } \\
68879\end{array}$ & KANACONO & DW4686 & $22^{\circ} 29^{\prime} \mathrm{S}, 167^{\circ} 31^{\prime} \mathrm{E}(249-255 \mathrm{~m}$ depth) & NEOGA1345-19 & 1 & 1 & 0 & 1 & 1 \\
\hline Cystiscidae & Persicula columbiana & $\begin{array}{l}\text { MNHN-IM-2013- } \\
74065\end{array}$ & MADIBENTHOS & AB152 & $\begin{array}{l}14^{\circ} 30^{\prime} 28^{\prime \prime} \mathrm{N}, 61^{\circ} 6^{\prime} 5^{\prime \prime} \mathrm{W}(20-23 \mathrm{~m} \\
\text { depth) }\end{array}$ & NEOGA1346-19 & 1 & 1 & 0 & 1 & 1 \\
\hline Cystiscidae & $\begin{array}{l}\text { Pachybathron aff. } \\
\text { cassidiforme }\end{array}$ & $\begin{array}{l}\text { MNHN-IM-2013- } \\
60401\end{array}$ & KARUBENTHOS 2 & DW4545 & $\begin{array}{l}16^{\circ} 29^{\prime} 42^{\prime \prime N} \mathrm{~N}, 61^{\circ} 31^{\prime} 25^{\prime \prime} \mathrm{W}(60-82 \mathrm{~m} \\
\text { depth) }\end{array}$ & NEOGA1347-19 & 1 & 1 & 1 & 1 & 1 \\
\hline Cystiscidae & Gibberula nebulosa & $\begin{array}{l}\text { MNHN-IM-2013- } \\
68353\end{array}$ & KANACONO & DW4661 & $22^{\circ} 48^{\prime} \mathrm{S}, 167^{\circ} 07^{\prime} \mathrm{E}$ (405-410 m depth) & NEOGA1348-19 & 1 & 1 & 0 & 1 & 1 \\
\hline Cystiscidae & Gibberula aff. moscatellii & $\begin{array}{l}\text { MNHN-IM-2013- } \\
57223\end{array}$ & ILES DU SALUT & SCO1 & $5^{\circ} 17^{\prime} 27^{\prime \prime} \mathrm{N}, 52^{\circ} 35^{\prime} 15^{\prime \prime} \mathrm{W}$ (6-9 m depth) & NEOGA1349-19 & 1 & 1 & 1 & 1 & 1 \\
\hline Cystiscidae & Persicula pulcherrima & $\begin{array}{l}\text { MNHN-IM-2013- } \\
74064\end{array}$ & MADIBENTHOS & AB152 & $\begin{array}{l}14^{\circ} 30^{\prime} 28^{\prime \prime} \mathrm{N}, 61^{\circ} 6^{\prime} 5^{\prime \prime} \mathrm{W}(20-23 \mathrm{~m} \\
\text { depth) }\end{array}$ & NEOGA1350-19 & 1 & 0 & 0 & 1 & 1 \\
\hline Cystiscidae & $\begin{array}{l}\text { Gibberula n. sp. (group } \\
\text { asellina) }\end{array}$ & $\begin{array}{l}\text { MNHN-IM-2013- } \\
50497\end{array}$ & KAVIENG 2014 & KS21 & $2^{\circ} 34^{\prime} 34^{\prime \prime} \mathrm{S}, 150^{\circ} 46^{\prime} 21^{\prime \prime} \mathrm{E}$ (4 m depth) & NEOGA1351-19 & 1 & 1 & 0 & 1 & 1 \\
\hline Cystiscidae & Gibberula sp. 3 & $\begin{array}{l}\text { MNHN-IM-2013- } \\
6195\end{array}$ & PAPUA NIUGINI & PB47 & $5^{\circ} 11^{\prime} 16^{\prime \prime S}, 145^{\circ} 49^{\prime} 33^{\prime \prime}$ (5 m depth) & NEOGA1352-19 & 1 & 1 & 0 & 1 & 1 \\
\hline Cystiscidae & Gibberula sp. 4 & $\begin{array}{l}\text { MNHN-IM-2013- } \\
2296\end{array}$ & PAPUA NIUGINI & PS11 & $5^{\circ} 4^{\prime} 45^{\prime \prime S}, 145^{\circ} 48^{\prime} 51^{\prime \prime} \mathrm{E}$ (5 m depth) & NEOGA1353-19 & 1 & 1 & 1 & 1 & 1 \\
\hline
\end{tabular}




\begin{tabular}{|c|c|c|c|c|c|c|c|c|c|c|c|}
\hline Cystiscidae & Gibberula sp. 2 & $\begin{array}{l}\text { MNHN-IM-2013- } \\
4208\end{array}$ & PAPUA NIUGINI & PB26 & $4^{\circ} 59^{\prime} 6^{\prime \prime} \mathrm{S}, 145^{\circ} 47^{\prime} 42^{\prime \prime} \mathrm{E}$ (22 m depth) & NEOGA1354-19 & 1 & 1 & 1 & 0 & 1 \\
\hline Cystiscidae & Plesiocystiscus sp. 1 & $\begin{array}{l}\text { MNHN-IM-2013- } \\
40708\end{array}$ & MADIBENTHOS & AB167 & $14^{\circ} 26.6^{\prime} \mathrm{N}, 60^{\circ} 53.9^{\prime} \mathrm{W}(11 \mathrm{~m}$ depth $)$ & NEOGA1355-19 & 1 & 1 & 1 & 1 & 1 \\
\hline Cystiscidae & Plesiocystiscus sp. 2 & $\begin{array}{l}\text { MNHN-IM-2013- } \\
43725\end{array}$ & GUYANE 2014 & CP4353 & $5^{\circ} 12^{\prime} 24^{\prime \prime} \mathrm{N}, 51^{\circ} 40^{\prime} 12^{\prime \prime} \mathrm{W}$ (60 m depth) & NEOGA1356-19 & 1 & 1 & 1 & 1 & 0 \\
\hline Marginellidae & Dentimargo n. sp. & $\begin{array}{l}\text { MNHN-IM-2013- } \\
45652\end{array}$ & MADEEP & DW4292 & $\begin{array}{l}9^{\circ} 13^{\prime} 49^{\prime \prime S}, 153^{\circ} 51^{\prime} 44^{\prime \prime \prime \prime} \mathrm{E}(530 \mathrm{~m} \\
\text { depth) }\end{array}$ & NEOGA1357-19 & 1 & 1 & 1 & 1 & 1 \\
\hline Marginellidae & Dentimargo sp. 3 & $\begin{array}{l}\text { MNHN-IM-2013- } \\
45628\end{array}$ & MADEEP & DW4290 & $9^{\circ} 13^{\prime} 6^{\prime \prime} \mathrm{S}, 153^{\circ} 53^{\prime} 45^{\prime \prime E}$ (593 m depth) & NEOGA1358-19 & 0 & 1 & 1 & 1 & 1 \\
\hline Marginellidae & Serrata tuii & $\begin{array}{l}\text { MNHN-IM-2013- } \\
69537\end{array}$ & KANACONO & DW4721 & $22^{\circ} 54^{\prime} \mathrm{S}, 167^{\circ} 15^{\prime} \mathrm{E}$ (473-490 m depth) & NEOGA1359-19 & 1 & 1 & 1 & 1 & 1 \\
\hline Marginellidae & Eratoidea cf. hematita & $\begin{array}{l}\text { MNHN-IM-2013- } \\
60596\end{array}$ & KARUBENTHOS 2 & DW4559 & $\begin{array}{l}16^{\circ} 24^{\prime} 31^{\prime \prime} \mathrm{N}, 60^{\circ} 51^{\prime} 51^{\prime \prime} \mathrm{W}(72-111 \mathrm{~m} \\
\text { depth) }\end{array}$ & NEOGA1360-19 & 1 & 1 & 1 & 1 & 1 \\
\hline Marginellidae & Dentimargo sp. & $\begin{array}{l}\text { MNHN-IM-2013- } \\
60848\end{array}$ & KARUBENTHOS 2 & DW4580 & $\begin{array}{l}16^{\circ} 18^{\prime} 54^{\prime \prime N}, 60^{\circ} 49^{\prime} 32^{\prime \prime} \mathrm{W}(412-500 \mathrm{~m} \\
\text { depth) }\end{array}$ & NEOGA1361-19 & 1 & 1 & 1 & 1 & 1 \\
\hline Marginellidae & Dentimargo biocal & $\begin{array}{l}\text { MNHN-IM-2013- } \\
69570\end{array}$ & KANACONO & DW4720 & $22^{\circ} 50^{\prime} \mathrm{S}, 167^{\circ} 11^{\prime} \mathrm{E}(374-400 \mathrm{~m}$ depth) & NEOGA1362-19 & 1 & 1 & 1 & 1 & 1 \\
\hline Marginellidae & Dentimargo cingulatus & $\begin{array}{l}\text { MNHN-IM-2013- } \\
69532\end{array}$ & KANACONO & DW4731 & $22^{\circ} 31^{\prime} \mathrm{S}, 167^{\circ} 35^{\prime} \mathrm{E}(457-460 \mathrm{~m}$ depth) & NEOGA1363-19 & 1 & 1 & 1 & 0 & 1 \\
\hline Marginellidae & Dentimargo caledonicus & $\begin{array}{l}\text { MNHN-IM-2013- } \\
69064\end{array}$ & KANACONO & DW4696 & $22^{\circ} 49^{\prime} \mathrm{S}, 167^{\circ} 15^{\prime} \mathrm{E}$ (445 m depth) & NEOGA1364-19 & 1 & 1 & 1 & 1 & 1 \\
\hline Marginellidae & Dentimargo n. sp. & $\begin{array}{l}\text { MNHN-IM-2013- } \\
69502\end{array}$ & KANACONO & DW4722 & $22^{\circ} 54^{\prime} S, 167^{\circ} 17^{\prime} \mathrm{E}$ (496-505m depth) & NEOGA1365-19 & 1 & 1 & 0 & 1 & 1 \\
\hline Marginellidae & Dentimargo sp. 1 & $\begin{array}{l}\text { MNHN-IM-2013- } \\
68580\end{array}$ & KANACONO & DW4666 & $22^{\circ} 53^{\prime} \mathrm{S}, 167^{\circ} 17^{\prime} \mathrm{E}(530-545 \mathrm{~m}$ depth) & NEOGA1366-19 & 1 & 1 & 1 & 1 & 1 \\
\hline Marginellidae & Marginella cloveri & $\begin{array}{l}\text { MNHN-IM-2013- } \\
56775\end{array}$ & GUYANE 2014 & CP4402 & $\begin{array}{l}6^{\circ} 17^{\prime} 58^{\prime \prime} \mathrm{N}, 52^{\circ} 13^{\prime} 19^{\prime \prime} \mathrm{W}(95-97 \mathrm{~m} \\
\text { depth) }\end{array}$ & NEOGA1367-19 & 1 & 1 & 1 & 1 & 1 \\
\hline Marginellidae & Dentimargo sp. & $\begin{array}{l}\text { MNHN-IM-2013- } \\
47685\end{array}$ & KAVIENG 2014 & KS11 & $2^{\circ} 33^{\prime} 10^{\prime \prime S}, 150^{\circ} 48^{\prime} 9^{\prime \prime} \mathrm{E}(7 \mathrm{~m}$ depth) & NEOGA1368-19 & 1 & 1 & 1 & 1 & 1 \\
\hline Marginellidae & $\begin{array}{l}\text { Hydroginella n. sp. (group } \\
\text { scintilla) }\end{array}$ & $\begin{array}{l}\text { MNHN-IM-2013- } \\
51961\end{array}$ & KAVIENG 2014 & KS35 & $2^{\circ} 38^{\prime} 47^{\prime \prime S}, 150^{\circ} 40^{\prime} 44^{\prime \prime} \mathrm{E}$ (4-5 m depth) & NEOGA1369-19 & 1 & 0 & 1 & 1 & 1 \\
\hline Marginellidae & Hydroginella cf. tridentata & $\begin{array}{l}\text { MNHN-IM-2013- } \\
43736\end{array}$ & $\begin{array}{l}\text { WESTERN } \\
\text { AUSTRALIA } 2011\end{array}$ & WE03 & $33^{\circ} 59^{\prime} 36^{\prime \prime S}, 122^{\circ} 13^{\prime} 13^{\prime \prime E}$ (11 m depth) & NEOGA1370-19 & 1 & 1 & 1 & 1 & 1 \\
\hline Marginellidae & Hydroginella sp. & $\begin{array}{l}\text { MNHN-IM-2013- } \\
5506\end{array}$ & PAPUA NIUGINI & PB37 & $5^{\circ} 15^{\prime} 55^{\prime \prime S}, 145^{\circ} 47^{\prime} 9^{\prime \prime} \mathrm{E}$ (10 m depth) & NEOGA1371-19 & 1 & 1 & 1 & 1 & 1 \\
\hline Marginellidae & Hydroginella sp. & $\begin{array}{l}\text { MNHN-IM-2013- } \\
50680\end{array}$ & KAVIENG 2014 & KB16 & $\begin{array}{l}2^{\circ} 34^{\prime} 34^{\prime \prime S}, 150^{\circ} 46^{\prime} 21^{\prime \prime E} \text { (13-14 m } \\
\text { depth) }\end{array}$ & NEOGA1372-19 & 0 & 1 & 1 & 1 & 1 \\
\hline Marginellidae & Mesoginella n. sp. & $\begin{array}{l}\text { MNHN-IM-2013- } \\
43731\end{array}$ & EXBODI & DW3785 & $\begin{array}{l}22^{\circ} 15^{\prime} 24^{\prime \prime} \mathrm{S}, 167^{\circ} 10^{\prime} 24^{\prime \prime} \mathrm{E}(386-387 \mathrm{~m} \\
\text { depth) }\end{array}$ & NEOGA1373-19 & 1 & 1 & 1 & 1 & 1 \\
\hline Marginellidae & Mesoginella sp. & $\begin{array}{l}\text { MNHN-IM-2013- } \\
68895\end{array}$ & KANACONO & DW4677 & $22^{\circ} 53^{\prime} \mathrm{S}, 167^{\circ} 35^{\prime} \mathrm{E}$ (376-390 m depth) & NEOGA1374-19 & 1 & 0 & 1 & 1 & 1 \\
\hline Marginellidae & Protoginella laseroni & $\begin{array}{l}\text { MNHN-IM-2013- } \\
69467\end{array}$ & KANACONO & DW4711 & $22^{\circ} 47^{\prime} \mathrm{S}, 167^{\circ} 24^{\prime} \mathrm{E}$ (325-338 m depth) & NEOGA1375-19 & 1 & 1 & 1 & 1 & 1 \\
\hline Marginellidae & Protoginella maestratii & $\begin{array}{l}\text { MNHN-IM-2013- } \\
69554\end{array}$ & KANACONO & DW4719 & $22^{\circ} 47^{\prime} \mathrm{S}, 167^{\circ} 05^{\prime} \mathrm{E}$ (335-350 m depth) & NEOGA1376-19 & 1 & 1 & 1 & 1 & 1 \\
\hline Marginellidae & Dentimargo sp. & $\begin{array}{l}\text { MNHN-IM-2013- } \\
68687\end{array}$ & KANACONO & DW4666 & $22^{\circ} 53^{\prime S} 167^{\circ} 17^{\prime} \mathrm{E}(530-545 \mathrm{~m})$ depth & NEOGA1377-19 & 1 & 0 & 1 & 1 & 1 \\
\hline Marginellidae & Mesoginella $\mathrm{n} . \mathrm{sp}$. & $\begin{array}{l}\text { MNHN-IM-2013- } \\
68948\end{array}$ & KANACONO & DW4690 & $22^{\circ} 59^{\prime} \mathrm{S}, 167^{\circ} 29^{\prime} \mathrm{E}(800 \mathrm{~m}$ depth) & NEOGA1378-19 & 1 & 1 & 0 & 1 & 1 \\
\hline Marginellidae & Dentimargo sp. & $\begin{array}{l}\text { MNHN-IM-2013- } \\
47082\end{array}$ & KAVIENG 2014 & KS19 & $2^{\circ} 34^{\prime} 1^{\prime \prime} \mathrm{S}, 150^{\circ} 47^{\prime} 5^{\prime \prime} \mathrm{E}(10 \mathrm{~m}$ depth) & NEOGA1379-19 & 1 & 1 & 1 & 1 & 1 \\
\hline
\end{tabular}




\begin{tabular}{|c|c|c|c|c|c|c|c|c|c|c|c|}
\hline Marginellidae & Marginella festiva & $\begin{array}{l}\text { MNHN-IM-2013- } \\
43709\end{array}$ & Dakar'09 & Stn. 9 & $14^{\circ} 39^{\prime} 54^{\prime \prime} \mathrm{N}, 17^{\circ} 24^{\prime} 0^{\prime \prime} \mathrm{W}$ (7 m depth) & NEOGA1380-19 & 1 & 1 & 1 & 1 & 1 \\
\hline Marginellidae & Glabella denticulata & $\begin{array}{l}\text { MNHN-IM-2013- } \\
43710\end{array}$ & Dakar'09 & Stn. 17 & $14^{\circ} 12^{\prime} 4^{\prime \prime} \mathrm{N}, 17^{\circ} 17^{\prime} 48^{\prime \prime} \mathrm{W}$ (43 m depth) & NEOGA1381-19 & 1 & 1 & 1 & 1 & 1 \\
\hline Marginellidae & Marginella lucani & $\begin{array}{l}\text { MNHN-IM-2013- } \\
43711\end{array}$ & Port ZANAGA & 553DW & $4^{\circ} 43^{\prime} 19^{\prime \prime S}, 11^{\circ} 48^{\prime} 6^{\prime \prime E}$ (13-14 m depth) & NEOGA1382-19 & 1 & 1 & 1 & 1 & 1 \\
\hline Marginellidae & Marginella sergioi & $\begin{array}{l}\text { MNHN-IM-2013- } \\
43713\end{array}$ & MAINBAZA & CP3133 & $\begin{array}{l}25^{\circ} 10^{\prime} 50^{\prime \prime} \mathrm{S}, 35^{\circ} 10^{\prime} 11^{\prime \prime}(200-201 \mathrm{~m} \\
\text { depth) }\end{array}$ & NEOGA1383-19 & 1 & 1 & 1 & 1 & 1 \\
\hline Marginellidae & Glabella rosadoi & $\begin{array}{l}\text { MNHN-IM-2013- } \\
43717\end{array}$ & INHACA 2011 & MR25 & $25^{\circ} 54^{\prime} 6^{\prime \prime S}, 33^{\circ} 3^{\prime} 6^{\prime \prime} \mathrm{E}$ (11-13 m depth) & NEOGA1384-19 & 1 & 1 & 1 & 1 & 1 \\
\hline Marginellidae & Volvarina cf. micans & $\begin{array}{l}\text { MNHN-IM-2013- } \\
43743\end{array}$ & INHACA 2011 & MS06 & $26^{\circ} 5^{\prime} 24^{\prime \prime S}, 33^{\circ} 0^{\prime} 30^{\prime \prime} \mathrm{E}$ (17-28 m depth) & NEOGA1385-19 & 1 & 1 & 1 & 1 & 1 \\
\hline Marginellidae & Volvarina janneefsi & $\begin{array}{l}\text { MNHN-IM-2019- } \\
1415 \\
\text { /Mr-PH-296 }\end{array}$ & - & - & $\begin{array}{l}\text { Philippines, Mactan Is., off Punta- } \\
\text { Engana (Iumun-lumun) }\end{array}$ & NEOGA1386-19 & 1 & 1 & 1 & 0 & 1 \\
\hline Marginellidae & Hyalina buskei & $\begin{array}{l}\text { MNHN-IM-2013- } \\
72397\end{array}$ & MADIBENTHOS & AR76 & $\begin{array}{l}14^{\circ} 27^{\prime} 54^{\prime \prime} \mathrm{N}, 61^{\circ} 1^{\prime} 10^{\prime \prime} \mathrm{W}(16-26 \mathrm{~m} \\
\text { depth) }\end{array}$ & NEOGA1387-19 & 1 & 1 & 1 & 1 & 1 \\
\hline Marginellidae & Volvarina cf. hennequini & $\begin{array}{l}\text { MNHN-IM-2013- } \\
56837\end{array}$ & GUYANE 2014 & CP4407 & $\begin{array}{l}6^{\circ} 53^{\prime} 6^{\prime \prime} \mathrm{N}, 52^{\circ} 33^{\prime} 28^{\prime \prime} \mathrm{W}(495-502 \mathrm{~m} \\
\text { depth) }\end{array}$ & NEOGA1388-19 & 1 & 1 & 0 & 1 & 1 \\
\hline Marginellidae & Volvarina constricta & $\begin{array}{l}\text { MNHN-IM-2013- } \\
43741\end{array}$ & Dakar'09 & Stn. 5 & $14^{\circ} 34^{\prime} 12^{\prime \prime} \mathrm{N}, 17^{\circ} 25^{\prime} 6^{\prime \prime} \mathrm{W}$ (31 m depth) & NEOGA1389-19 & 1 & 1 & 1 & 1 & 1 \\
\hline Marginellidae & Volvarina aff. avena & $\begin{array}{l}\text { MNHN-IM-2013- } \\
60828\end{array}$ & KARUBENTHOS 2 & DW4579 & $\begin{array}{l}16^{\circ} 21^{\prime} 20^{\prime \prime} \mathrm{N}, 60^{\circ} 53^{\prime} 39^{\prime \prime} \mathrm{W}(228-264 \mathrm{~m} \\
\text { depth) }\end{array}$ & NEOGA1390-19 & 1 & 1 & 1 & 1 & 1 \\
\hline Marginellidae & Volvarina aff. lactea & $\begin{array}{l}\text { MNHN-IM-2013- } \\
60956\end{array}$ & KARUBENTHOS 2 & DW4590 & $\begin{array}{l}15^{\circ} 57^{\prime} 28^{\prime \prime} \mathrm{N}, 61^{\circ} 27^{\prime} 28^{\prime \prime} \mathrm{W}(83-135 \mathrm{~m} \\
\text { depth) }\end{array}$ & NEOGA1391-19 & 1 & 1 & 1 & 1 & 0 \\
\hline Marginellidae & Prunum prunum & $\begin{array}{l}\text { MNHN-IM-2013- } \\
56949\end{array}$ & ILES DU SALUT & SR1 & $5^{\circ} 17^{\prime} 9^{\prime \prime} \mathrm{N}, 52^{\circ} 35^{\prime} 14^{\prime \prime} \mathrm{W}$ (0-6 m depth) & NEOGA1392-19 & 1 & 1 & 1 & 1 & 1 \\
\hline Marginellidae & Prunum marginatum & $\begin{array}{l}\text { MNHN-IM-2013- } \\
56142\end{array}$ & GUYANE 2014 & CP4344 & $5^{\circ} 8^{\prime} 40^{\prime \prime} \mathrm{N}, 51^{\circ} 58^{\prime} 40^{\prime \prime} \mathrm{W}$ (47 m depth) & NEOGA1393-19 & 1 & 1 & 0 & 1 & 1 \\
\hline Marginellidae & Volvarina armonica & $\begin{array}{l}\text { MNHN-IM-2013- } \\
68535\end{array}$ & KANACONO & DW4661 & $22^{\circ} 48^{\prime} S, 167^{\circ} 07^{\prime} E$ (405-410 m depth) & NEOGA1394-19 & 1 & 1 & 0 & 1 & 1 \\
\hline Marginellidae & Closia sp. & $\begin{array}{l}\text { MNHN-IM-2009- } \\
14753\end{array}$ & ATIMO VATAE & DW3607 & $\begin{array}{l}24^{\circ} 39^{\prime} 26^{\prime \prime S}, 47^{\circ} 31^{\prime} 43^{\prime \prime} \mathrm{E}(86-87 \mathrm{~m} \\
\text { depth) }\end{array}$ & NEOGA1395-19 & 1 & 1 & 1 & 1 & 1 \\
\hline Marginellidae & Closia giadae & $\begin{array}{l}\text { MNHN-IM-2009- } \\
14754\end{array}$ & ATIMO VATAE & DW3607 & $\begin{array}{l}25^{\circ} 45^{\prime} 44^{\prime \prime S}, 44^{\circ} 51^{\prime} 59^{\prime \prime} \mathrm{E}(40-41 \mathrm{~m} \\
\text { depth) }\end{array}$ & NEOGA1396-19 & 1 & 1 & 0 & 1 & 1 \\
\hline Marginellidae & Granulina liliputana & $\begin{array}{l}\text { MNHN-IM-2013- } \\
43723\end{array}$ & Dakar'09 & Stn. 10 & $14^{\circ} 39^{\prime} 48^{\prime \prime} \mathrm{N}, 17^{\circ} 23^{\prime} 54^{\prime \prime} \mathrm{W}$ (31 m depth) & NEOGA1397-19 & 1 & 1 & 1 & 1 & 0 \\
\hline Marginellidae & Granulina marginata & PAlbano_G2 & - & - & Greece, Crete & - & 1 & 0 & 1 & 0 & 1 \\
\hline Marginellidae & Marginellona gigas & $\begin{array}{l}\text { MNHN-IM-2013- } \\
50159\end{array}$ & DongSha 2014 & CP4127 & $\begin{array}{l}20^{\circ} 46^{\prime} 14^{\prime \prime} \mathrm{N}, 116^{\circ} 7^{\prime} 59^{\prime \prime} \mathrm{E}(392-408 \mathrm{~m} \\
\text { depth) }\end{array}$ & NEOGA1398-19 & 1 & 1 & 1 & 1 & 1 \\
\hline \multicolumn{12}{|l|}{ OUTGROUP } \\
\hline Volutidae & Lyria & $\begin{array}{l}\text { MNHN-IM-2009- } \\
7377\end{array}$ & MAINBAZA & CP3144 & $23^{\circ} 33^{\prime} \mathrm{S}, 35^{\circ} 41^{\prime} \mathrm{E}$ (171-180 m depth) & NEOGA1399-19 & 1 & 0 & 1 & 1 & 1 \\
\hline Volutidae & Fulgoraria & $\begin{array}{l}\text { MNHN-IM-2013- } \\
44037\end{array}$ & NanHai 2014 & CP4099 & $22^{\circ} 13^{\prime} \mathrm{N}, 120^{\circ} 24^{\prime} \mathrm{E}$ (310-346 m depth) & NEOGA1400-19 & 1 & 1 & 1 & 1 & 1 \\
\hline Volutidae & Calliotectum & $\begin{array}{l}\text { MNHN-IM-2013- } \\
50202\end{array}$ & DongSha 2014 & CP4129 & $20^{\circ} 29^{\prime} \mathrm{N}, 116^{\circ} 08^{\prime} \mathrm{E}$ (590-633 m depth) & NEOGA1401-19 & 1 & 1 & 1 & 1 & 1 \\
\hline Volutidae & Volutocorbis sp. & $\begin{array}{l}\text { MNHN-IM-2009- } \\
9486\end{array}$ & MAINBAZA & CP3146 & $21^{\circ} 38^{\prime} \mathrm{S}, 36^{\circ} 07^{\prime} \mathrm{E}$ (1161-1185 m depth) & NEOGA1402-19 & 1 & 1 & 0 & 1 & 1 \\
\hline Cancellariidae & Scalptia textilis & $\begin{array}{l}\text { MNHN-IM-2009- } \\
10506\end{array}$ & & & $\begin{array}{l}\text { Philippines, off Olango Is. (10 m } \\
\text { depth) }\end{array}$ & CANC093-10 & FR717505 & FR718353 & FR718426 & 0 & 1 \\
\hline
\end{tabular}




\begin{tabular}{|c|c|c|c|}
\hline Cancellariidae & Cancellaria cancellata & BAU00224 & - \\
\hline Cancellariidae & Plesiotriton silinoensis & $\begin{array}{l}\text { MNHN-IM-2007- } \\
32123\end{array}$ & $\begin{array}{l}\text { PANGLAO } 2005 \\
\text { Deep }\end{array}$ \\
\hline CharitodoronidaeE & Charitodoron bathybius & $\begin{array}{l}\text { MNHN-IM-2007- } \\
38306\end{array}$ & MAINBAZA \\
\hline Mitridae & Mitra glabra & $\begin{array}{l}\text { MNHN-IM-2013- } \\
40640\end{array}$ & $\begin{array}{l}\text { WESTERN } \\
\text { AUSTRALIA } 2011\end{array}$ \\
\hline Mitridae & Neocancilla papilio & $\begin{array}{l}\text { MNHN-IM-2013- } \\
12560\end{array}$ & PAPUA NIUGINI \\
\hline Pyrammitridae & Teremitra efatensis & $\begin{array}{l}\text { MNHN-IM-2013- } \\
52074\end{array}$ & PAPUA NIUGINI \\
\hline Harpidae & Harpa harpa & $\begin{array}{l}\text { MNHN-IM-2013- } \\
51800\end{array}$ & KAVIENG 2014 \\
\hline Muricidae & Murex trapa & LSGB23004 & - \\
\hline Muricidae & Vasula speciosa & CNMO3105 & - \\
\hline Muricidae & Rapana venosa & NHMUK20100317 & - \\
\hline Muricidae & Leptotrophon surprisensis & $\begin{array}{l}\text { MNHN-IM-2009- } \\
8589\end{array}$ & EBISCO \\
\hline Muricidae & Pterymarchia martinetana & $\begin{array}{l}\text { MNHN-IM-2009- } \\
5011\end{array}$ & SANTO 2006 \\
\hline Muricidae & Vitularia miliaris & $\begin{array}{l}\text { MNHN-IM-2009- } \\
5030\end{array}$ & SANTO 2006 \\
\hline Belloliviae & Olivellopsis simplex & $\begin{array}{l}\text { MNHN-IM-2013- } \\
47678\end{array}$ & KAVIENG 2014 \\
\hline Benthobiidae & Benthobia sp. 2 & $\begin{array}{l}\text { MNHN-IM-2013- } \\
18534\end{array}$ & PAPUA NIUGINI \\
\hline Ancillariidae & Amalda optima & $\begin{array}{l}\text { MNHN-IM-2009- } \\
22263\end{array}$ & INHACA 2011 \\
\hline Olividae & Olivella sp. & $\begin{array}{l}\text { MNHN-IM-2009- } \\
24367\end{array}$ & $\begin{array}{l}\text { KARUBENTHOS } \\
2012\end{array}$ \\
\hline Olividae & Oliva amethystina & $\begin{array}{l}\text { MNHN-IM-2007- } \\
31988\end{array}$ & SANTO 2006 \\
\hline Pseudolividae & Fulmentum sepimentum & $\begin{array}{l}\text { MNHN-IM-2013- } \\
52003\end{array}$ & Port ZANAGA \\
\hline Columbariidae & Coluzea juliae & $\begin{array}{l}\text { MNHN-IM-2007- } \\
38972\end{array}$ & MAINBAZA \\
\hline Costellariidae & Ceratoxancus sp. & $\begin{array}{l}\text { MNHN-IM-2007- } \\
38552\end{array}$ & TARASOC \\
\hline Costellariidae & Vexillum exasperatum & $\begin{array}{l}\text { MNHN-IM-2013- } \\
11680\end{array}$ & PAPUA NIUGINI \\
\hline Ptychatractidae & Exilia krigei & $\begin{array}{l}\text { MNHN-IM-2007- } \\
38331\end{array}$ & MAINBAZA \\
\hline Vasidae & Vasum globulus & $\begin{array}{l}\text { MNHN-IM-2013- } \\
8329\end{array}$ & $\begin{array}{l}\text { KARUBENTHOS } \\
2012\end{array}$ \\
\hline Vasidae & Vasum muricatum & $\begin{array}{l}\text { MNHN-IM-2013- } \\
20017\end{array}$ & $\begin{array}{l}\text { KARUBENTHOS } \\
2012\end{array}$ \\
\hline Vasidae & Vasum turbinellus & LSGB23801 & - \\
\hline Volutomitridae & Exilioidea sp. & $\begin{array}{l}\text { MNHN-IM-2013- } \\
40625\end{array}$ & PAPUA NIUGINI \\
\hline Volutomitridae & Volutomitra glabella & $\begin{array}{l}\text { MNHN-IM-2007- } \\
35070\end{array}$ & CONCALIS \\
\hline
\end{tabular}

\begin{tabular}{|c|c|}
\hline & off Malaga (Spain) (40-50 m depth) \\
\hline 359 & $08^{\circ} 50^{\prime} \mathrm{N}, 123^{\circ} 35^{\prime} \mathrm{E}$ (437-476 m depth) \\
\hline 57 & $21^{\circ} 46^{\prime} \mathrm{S}, 36^{\circ} 25^{\prime} \mathrm{E}$ (1410-1416 m depth) \\
\hline E01 & $15^{\circ} 16.94^{\prime} \mathrm{S}, 124^{\circ} 06.3^{\prime} \mathrm{E}$ (11 m depth) \\
\hline PR24 & $05^{\circ} 12.3^{\prime} \mathrm{S}, 145^{\circ} 48.8^{\prime} \mathrm{E}$ \\
\hline CP4058 & $02^{\circ} 55^{\prime} \mathrm{S}, 142^{\circ} 11^{\prime} \mathrm{E}(535-540 \mathrm{~m})$ depth \\
\hline KR62 & $02^{\circ} 41.6^{\prime} \mathrm{S}, 150^{\circ} 38.9^{\prime} \mathrm{E}$ (10-11 m depth) \\
\hline & $21^{\circ} 26^{\prime} \mathrm{S}, 109^{\circ} 02^{\prime} \mathrm{E}$ \\
\hline- & Claremont et al. (2012) \\
\hline - & Claremont et al. (2012) \\
\hline DW2610 & $19^{\circ} 34^{\prime} \mathrm{S}, 158^{\circ} 41^{\prime} \mathrm{E}$ (486-494 m depth) \\
\hline FR45 & $15^{\circ} 27^{\prime \prime S}, 167^{\circ} 13.5^{\prime} \mathrm{E}$ (0-7 m depth) \\
\hline DR84 & $15^{\circ} 43.4^{\prime} \mathrm{S}, 167^{\circ} 15^{\prime} \mathrm{E}$ (6 m depth) \\
\hline KS11 & $02^{\circ} 33.2^{\prime} \mathrm{S}, 150^{\circ} 48.2^{\prime} \mathrm{E}$ (7 m depth) \\
\hline CP4038 & $04^{\circ} 27^{\prime} \mathrm{S}, 145^{\circ} 34^{\prime} \mathrm{E}$ (800-840 m depth) \\
\hline MR4 & $26^{\circ} 06.3^{\prime} \mathrm{S}, 32^{\circ} 58.0^{\prime} \mathrm{E}$ (17-19 m depth) \\
\hline GD41 & $16^{\circ} 20,91^{\prime} \mathrm{N}, 61^{\circ} 32.23^{\prime} \mathrm{W}$ ( $2 \mathrm{~m}$ depth $)$ \\
\hline DR09 & $15^{\circ} 34.6^{\prime} \mathrm{S}, 167^{\circ} 13.8^{\prime} \mathrm{E}(12 \mathrm{~m}$ depth) \\
\hline D502 & $04^{\circ} 42,25^{\prime} \mathrm{S}, 11^{\circ} 47^{\prime} \mathrm{E}$ (16 m depth) \\
\hline CP3139 & $23^{\circ} 35^{\prime} \mathrm{S}, 36^{\circ} 06^{\prime} \mathrm{E}$ (1092-1195 m depth) \\
\hline DW3401 & $15^{\circ} 51^{\prime} \mathrm{S}, 148^{\circ} 18^{\prime} \mathrm{W}$ (789-831 m depth) \\
\hline PR14 & $05^{\circ} 12^{\prime} \mathrm{S}, 145^{\circ} 48,1^{\prime} \mathrm{E}$ (2-3 m depth) \\
\hline сC3171 & $25^{\circ} 59^{\prime} \mathrm{S}, 34^{\circ} 42^{\prime} \mathrm{E}$ (771-776 m depth) \\
\hline GM02 & $16^{\circ} 20,45^{\prime} \mathrm{N}, 61^{\circ} 31,55^{\prime} \mathrm{W}(1 \mathrm{~m}$ depth $)$ \\
\hline GM02 & $16^{\circ} 20,45^{\prime} \mathrm{N}, 61^{\circ} 31,55^{\prime} \mathrm{W}$ (1 m depth) \\
\hline & $18^{\circ} 28^{\prime} \mathrm{S}, 110^{\circ} 04^{\prime} \mathrm{E}$ \\
\hline CP3963 & $05^{\circ} 06^{\prime} \mathrm{S}, 145^{\circ} 53^{\prime} \mathrm{E}$ (960-980 m depth) \\
\hline & $18^{\circ} 34^{\prime} \mathrm{S}, 163^{\circ} 08^{\prime} \mathrm{E}(450-454 \mathrm{~m} \mathrm{~d}$ \\
\hline
\end{tabular}

CANC028-10
MITRI057-15
MITRI042-15
MITRI034-15
MITRI078-15
NEOGA1403-19

\begin{tabular}{|c|c|c|c|c|}
\hline FM999157 & FM999105 & FM999074 & 0 & FM999136 \\
\hline FM999158 & FM999106 & FM999075 & 0 & FM999137 \\
\hline KR087240 & KR087994 & KR087335 & KR088081 & 1 \\
\hline KR087272 & KR088022 & KR087365 & KR088105 & 1 \\
\hline KR087287 & KR088037 & KR087376 & KR088116 & 1 \\
\hline KR087298 & KR088047 & KR087383 & KR088125 & 0 \\
\hline 1 & 1 & 1 & 1 & 1 \\
\hline GU188199 & GU188090 & GU188086 & HQ834146 & HM583721 \\
\hline HE584393 & HE584316 & HE584149 & KT754141 & HE584223 \\
\hline HE584367 & HE584279 & HE584116 & HQ834144 & HE584197 \\
\hline GU575381 & FN651925 & FN651880 & 0 & FN651991 \\
\hline GU575384 & FN651905 & FN651863 & 0 & FN651971 \\
\hline GU575391 & FN651922 & FN651877 & 0 & FN651988 \\
\hline KX233351 & KX233413 & KX233450 & KX233476 & 1 \\
\hline KX233315 & KX233405 & KX233442 & KX233473 & 1 \\
\hline KR087230 & KR087986 & KR087327 & KR088073 & 1 \\
\hline KR087290 & KR088040 & KR087378 & KR088119 & 1 \\
\hline KR087289 & KR088039 & KR087377 & KR088118 & 1 \\
\hline KR087261 & KR088012 & KR087354 & KR088098 & 1 \\
\hline KR087242 & KR087995 & KR087336 & KR088083 & 1 \\
\hline KR087238 & KR087993 & KR087334 & KR088079 & 1 \\
\hline KR087305 & KR088055 & KR087393 & KR088133 & 1 \\
\hline KR087257 & KR088009 & KR087352 & KR088096 & 1 \\
\hline KU986430 & KU873939 & KU876544 & KU876559 & 1 \\
\hline KU986431 & KU873940 & KU876545 & KU876560 & 0 \\
\hline HQ834084 & JN052960 & HQ833909 & HQ834180 & 0 \\
\hline KR087260 & KR088011 & KR087353 & 0 & 1 \\
\hline KR087319 & KR088064 & KR087406 & KR088145 & 1 \\
\hline
\end{tabular}




\begin{tabular}{|c|c|c|c|c|c|c|c|c|c|c|c|}
\hline Babyloniidae & Babylonia areolata & LSGB23411 & - & & Zou et al. (2011) & - & JN053013 & JN052948 & HQ833886 & HQ834157 & 0 \\
\hline Belomitridae & Belomitra paschalis & $\begin{array}{l}\text { MNHN-IM-2009- } \\
18853\end{array}$ & - & CP3138 & $25^{\circ} 13^{\prime} \mathrm{S}, 35^{\circ} 21^{\prime} \mathrm{E}$ (700-707 m depth) & NEOGA1145-11 & JQ950229 & JQ950147 & 0 & 1 & JQ950188 \\
\hline Buccinidae & Metula sp. & $\begin{array}{l}\text { MNHN-IM-2007- } \\
30079\end{array}$ & - & CP2348 & $09^{\circ} 30^{\prime} \mathrm{N}, 123^{\circ} 53^{\prime} \mathrm{E}$ (196-216 m depth) & NEOGA239-10 & KC756067 & 1 & KC756031 & 1 & KC756010 \\
\hline Buccinidae & Volutharpa perryi & LSGB23204 & - & - & Zou et al. (2011) & - & JN053002 & JN052939 & HQ833869 & HQ834141 & FJ710108 \\
\hline Buccinidae & Turrilatirus turritus & $\begin{array}{l}\text { MNHN-IM-2013- } \\
17100\end{array}$ & - & PR162 & $05^{\circ} 10.1^{\prime} \mathrm{S}, 145^{\circ} 50.2^{\prime} \mathrm{E}$ (1-4 m depth) & FASCI028-17 & KT753981 & KT753869 & 1 & KT754111 & KT753748 \\
\hline Melongenidae & Melongena melongena & $\begin{array}{l}\text { MNHN-IM-2013- } \\
71405\end{array}$ & - & AM032 & $14^{\circ} 42.9^{\prime} \mathrm{N}, 60^{\circ} 56.1^{\prime} \mathrm{W}(0 \mathrm{~m})$ & NEOGA1404-19 & 1 & 1 & 1 & 1 & 1 \\
\hline Nassariidae & Buccinanops cochlidium & MZUSP108269 & - & - & $\begin{array}{l}\text { Galindo et al. (2016): } 14^{\circ} 42.9^{\prime} \mathrm{N}, \\
60^{\circ} 56.1^{\prime} \mathrm{W}(0 \mathrm{~m})\end{array}$ & - & KY451221 & KY488731 & KY488928 & KY489295 & KY489126 \\
\hline Borsoniidae & Bathytoma neocaledonica & $\begin{array}{l}\text { MNHN-IM-2007- } \\
17857\end{array}$ & EBISCO & CP2551 & $21^{\circ} 06^{\prime} \mathrm{S}, 158^{\circ} 35^{\prime} \mathrm{E}$ (637-650 m depth) & CONO187-08 & EU015653 & HQ401661 & HQ401591 & EU015761 & EU015537 \\
\hline Clathurellidae & Etrema polydesma & $\begin{array}{l}\text { MNHN-IM-2007- } \\
17869\end{array}$ & PANGLAO 2004 & S21 & $09^{\circ} 41.7^{\prime} \mathrm{N}, 123^{\circ} 50.9^{\prime} \mathrm{E}$ (4-12 m depth) & CONO249-08 & EU015691 & HQ401675 & HQ401608 & EU015800 & EU015576 \\
\hline Cochlespiridae & Sibogasyrinx sp. & $\begin{array}{l}\text { MNHN-IM-2007- } \\
17703\end{array}$ & BOA1 & CP2432 & $15^{\circ} 00^{\prime} \mathrm{S}, 166^{\circ} 55^{\prime} \mathrm{E}$ (630-705 m depth) & CONO155-08 & 1 & 1 & 1 & EU015756 & EU015531 \\
\hline Conidae & Conasprella pagoda & $\begin{array}{l}\text { MNHN-IM-2007- } \\
17914\end{array}$ & PANGLAO 2005 & CP2380 & $08^{\circ} 41^{\prime} \mathrm{N}, 123^{\circ} 18^{\prime} \mathrm{E}$ (150-163 m depth) & CONO313-08 & EU015729 & FJ868151 & FJ868136 & EU015836 & EU015614 \\
\hline Conidae & Conus consors & $\begin{array}{l}\text { MNHN-IM-2007- } \\
17939\end{array}$ & SANTO 2006 & AT87 & $15^{\circ} 31^{\prime} \mathrm{S}, 167^{\circ} 17^{\prime} \mathrm{E}$ (235-271 m depth) & CONO513-08 & EU015751 & HQ401672 & HQ401605 & EU015858 & EU015636 \\
\hline Drilliidae & Clavus canalicularis & $\begin{array}{l}\text { MNHN-IM-2007- } \\
17858\end{array}$ & PANGLAO 2004 & S12 & $09^{\circ} 29,4^{\prime} \mathrm{N}, 123^{\circ} 56^{\prime} \mathrm{E}(6-8 \mathrm{~m}$ depth) & CONO229-08 & EU015680 & HQ401668 & HQ401601 & EU015789 & EU015565 \\
\hline Mangeliidae & $\begin{array}{l}\text { Citharomangelia } \\
\text { planilabroides }\end{array}$ & $\begin{array}{l}\text { MNHN-IM-2007- } \\
17896\end{array}$ & PANGLAO 2004 & D5 & $09^{\circ} 33.6^{\prime} \mathrm{N}, 123^{\circ} 43.5^{\prime} \mathrm{E}$ (0-3 m depth) & CONO219-08 & EU015670 & 1 & 1 & EU015779 & EU015555 \\
\hline Mitromorphidae & Mitromorpha metula & $\begin{array}{l}\text { MNHN-IM-2007- } \\
17898\end{array}$ & PANGLAO 2004 & B8 & $09^{\circ} 37.1^{\prime} \mathrm{N}, 123^{\circ} 46.1^{\prime} \mathrm{E}(3 \mathrm{~m}$ depth) & CONO221-08 & EU015672 & HQ401697 & HQ401633 & EU015781 & EU015557 \\
\hline Pseudomelatomidae & Funa hadra & $\begin{array}{l}\text { MNHN-IM-2007- } \\
17843\end{array}$ & EBISCO & DW2522 & $22^{\circ} 46^{\prime} \mathrm{S}, 159^{\circ} 21^{\prime} \mathrm{E}$ (310-318 m depth) & CONO182-08 & EU015648 & 1 & 1 & EU015757 & EU015532 \\
\hline Raphitomidae & Thatcheria mirabilis & $\begin{array}{l}\text { MNHN-IM-2007- } \\
17924\end{array}$ & SALOMON 2 & CP2184 & $08^{\circ} 17^{\prime} \mathrm{S}, 160^{\circ} 00^{\prime} \mathrm{E}$ (464-523 m depth) & CONO349-08 & EU015736 & FJ868138 & FJ868124 & EU015843 & EU015621 \\
\hline Terebridae & Terebra fujitai & $\begin{array}{l}\text { MNHN-IM-2007- } \\
15724\end{array}$ & PANGLAO 2005 & CP2343 & $09^{\circ} 27^{\prime} \mathrm{N}, 123^{\circ} 49^{\prime} \mathrm{E}$ (273-356 m depth) & CONO306-08 & EU015725 & EU685668 & EU685377 & EU015832 & EU015610 \\
\hline Turridae & Turris babylonia & $\begin{array}{l}\text { MNHN-IM-2007- } \\
17754\end{array}$ & PANGLAO 2004 & R42 & $09^{\circ} 37,1^{\prime} \mathrm{N}, 123^{\circ} 52,6^{\prime} \mathrm{E}$ (8-22 m depth) & CONO226-08 & EU015677 & HQ401715 & HQ401652 & EU015786 & EU015562 \\
\hline Bursidae & Bursa lamarckii & $\begin{array}{l}\text { MNHN-IM-2007- } \\
43066\end{array}$ & - & R24 & $09^{\circ} 37.5^{\prime} \mathrm{N}, 123^{\circ} 46.8^{\prime} \mathrm{E}(0-2 \mathrm{~m}$ depth) & TON0113-12 & JX241371 & $J \times 241125$ & 1 & 1 & JX241164 \\
\hline Cassidae & Galeodea bituminata & $\begin{array}{l}\text { MNHN-IM-2007- } \\
33627\end{array}$ & - & AT102 & $15^{\circ} 03^{\prime} \mathrm{S}, 166^{\circ} 53^{\prime} \mathrm{E}$ (517-547 m depth) & TONO236-18 & MH581335 & MH571354 & MH571268 & 1 & MH571198 \\
\hline Ficidae & Ficus filosa & $\begin{array}{l}\text { MNHN-IM-2007- } \\
33633\end{array}$ & - & T31 & $09^{\circ} 33^{\prime} \mathrm{N}, 123^{\circ} 42^{\prime} \mathrm{E}$ (100-140 m depth) & LITOR137-10 & MH581334 & MH571353 & MH571267 & 1 & MH571197 \\
\hline Personidae & Distorsio reticularis & $\begin{array}{l}\text { MNHN-IM-2007- } \\
34733\end{array}$ & - & CP2665 & $15^{\circ} 54^{\prime} \mathrm{N}, 121^{\circ} 42^{\prime} \mathrm{E}(123-125 \mathrm{~m}$ depth) & TONO194-18 & MH581323 & MH571342 & MH571259 & 1 & MH571190 \\
\hline Tonnidae & Tonna perdix & $\begin{array}{l}\text { MNHN-IM-2007- } \\
33629\end{array}$ & - & R34 & $09^{\circ} 35.9^{\prime} \mathrm{N}, 123^{\circ} 44.7^{\prime} \mathrm{E}$ (1-12 m depth) & TONO200-18 & MH581379 & MH571401 & MH571309 & 1 & MH571231 \\
\hline Xenophoridae & Xenophora sp. & $\begin{array}{l}\text { MNHN-IM-2019- } \\
1413 \\
\text { /Xe-NT-76 }\end{array}$ & NT & & $\begin{array}{l}\text { Vietnam, Nha Trang Bay, S. Mot Is. } \\
\text { (15-18 m depth) }\end{array}$ & NEOGA1405-19 & 1 & 1 & 1 & 0 & 1 \\
\hline
\end{tabular}




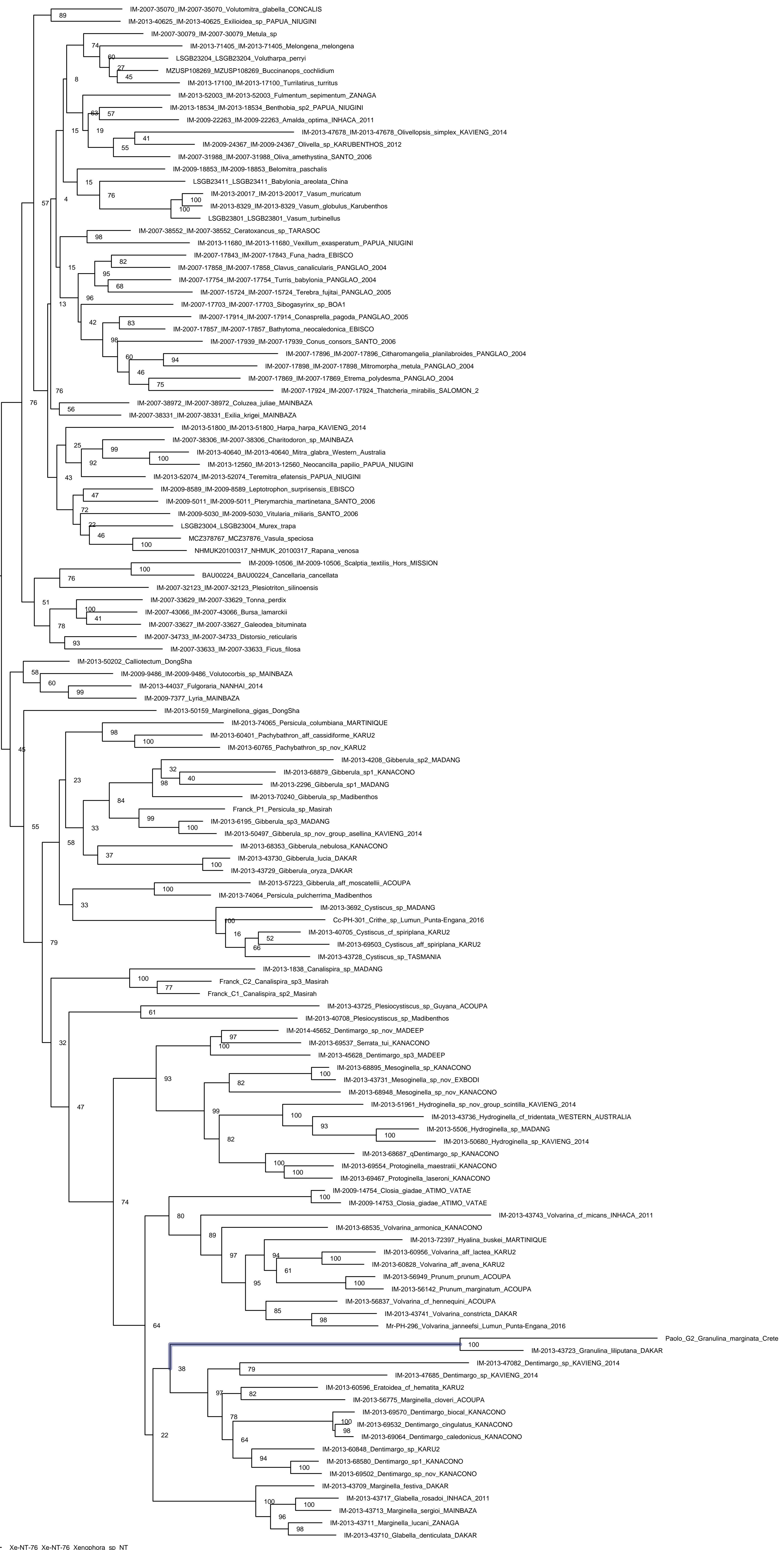

